TALYTA THEREZA SOARES D'EPIRO

\title{
ESTRUTURA POPULACIONAL, CARACTERÍSTICAS FENOTÍPICAS E VARIABILIDADE DO LÓCUS DE SÍNTESE DO POLISSACARÍDEO CAPSULAR DE AMOSTRAS DE PORPHYROMONAS GINGIVALIS
}

Dissertação apresentada ao Programa de Pós-Graduação em Microbiologia do Instituto de Ciências Biomédicas da Universidade de São Paulo, para a obtenção do Título de Mestre em Ciências. 


\section{ESTRUTURA POPULACIONAL, CARACTERÍSTICAS FENOTIIPICAS E VARIABILIDADE DO LÓCUS DE SÍNTESE DO POLISSACARÍDEO CAPSULAR DE AMOSTRAS DE PORPHYROMONAS GINGIVALIS}

Dissertação apresentada ao Programa
de Pós-Graduação em Microbiologia do
Instituto de Ciências Biomédicas da
Universidade de São Paulo, para a
obtenção do Título de Mestre em
Ciências.

Área de concentração: Microbiologia Orientador (a): Profa. Dra. Márcia Pinto Alves Mayer

Versão Original 
DADOS DE CATALOGAÇÃO NA PUBLICAÇÃO (CIP)

Serviço de Biblioteca e Informação Biomédica do

Instituto de Ciências Biomédicas da Universidade de São Paulo

(C) reprodução total

D'Epiro, Talyta Thereza Soares.

Estrutura populacional, características fenotípicas e variabilidade do lócus de síntese do polissacarídeo capsular de amostras de Porphyromonas gingivalis / Talyta Thereza Soares D'Epiro. -- São Paulo, 2011.

Orientador: Marcia Pinto Alves Mayer.

Dissertação (Mestrado) - Universidade de São Paulo. Instituto de Ciências Biomédicas. Departamento de Microbiologia. Área de concentração: Microbiologia. Linha de pesquisa: Microbiologia oral.

Versão do título para o inglês: Population structure, phenotypic characteristics and variability of locus of synthesis of the capsular polysaccharide of Porphyromonas gingivalis samples.

Descritores: 1. Periodontite crônica 2. Porphyromonas gingivalis 3 . Fatores de virulência 4. Cápsulas I. Mayer, Marcia Pinto Alves II. Universidade de São Paulo. Instituto de Ciências Biomédicas. Programa de Pós-Graduação em Microbiologia III. Título. 
UNIVERSIDADE DE SÃO PAULO

INSTITUTO DE CIÊNCIAS BIOMÉDICAS

Candidato(a):

Título da Dissertação:

Orientador(a):
Talyta Thereza Soares D'Epiro.

Estrutura populacional, características fenotipicas e variabilidade do lócus de síntese do polissacarídeo capsular de amostras de Porphyromanas gingivalis.

Marcia Pinto Alves Mayer.

A Comissão Julgadora dos trabalhos de Defesa da Dissertação de Mestrado, em sessão pública realizada a

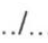
( ) Aprovado(a)
( ) Reprovado(a)
Examinador(a): Assinatura:
Nome:
Instituição:
Examinador(a): Assinatura:
Nome:
Instituição:
Presidente: Assinatura:
Nome:
Instituição:




\section{UNIVERSIDADE DE SÃO PAULO}

INSTITUTO DE CIÊNCIAS BIOMÉDICAS

Cidade Universitária "Armando de Salles Oliveira"

Av. Prof. Lineu Prestes, 2415 - cep. 05508-000 São Paulo, SP - Brasil

Telefone :(55) (11) 3091.7733 telefax : (55) (11) 3091-7438

e-mail: cep@ icb.usp.br

São Paulo, 18 de junho de 2009.

\section{PARECER 903/CEP}

Prezada Senhora,

Atendendo sua solicitação, a Comissão de Ética em Pesquisas com Seres Humanos do ICB, em sua $96^{\mathrm{a}}$ reunião realizada em 16.06 .09 , analisou o projeto de sua responsabilidade intitulado: "Análise da produção de cápsula e da variabilidade do lócus de síntese do polissacarídeo capsular em amostras de Porphyromonas gingivalis".

Informo a V.Sa. que, após análise e discussão, o referido projeto foi aprovado por esta Comissão.

Lembramos que cabe ao pesquisador elaborar e apresentar a este Comitê, relatórios anuais (parciais ou final), de acordo com a resolução 196/06 do Conselho Nacional da Saúde, item IX.2 letra c.

O primeiro relatório deverá ser encaminhado à Secretaria deste CEP em 16 de junho de 2010.

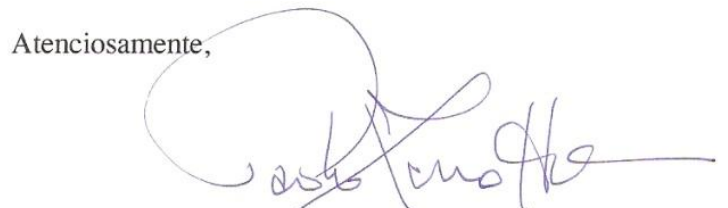

Prof. Dr. PAOlo M.A ZanotTo

Vice-Coordenador da Comissão de Ética em

Pesquisas com Seres Humanos - ICB/USP

Ilma Sra.

TALYTA THEREZA SOARES D`EPIRO

Departamento de Microbiologia

Instituto de Ciências Biomédicas -USP

Comissão de Ética em Pesquisa com Seres Humanos do Instituto de Ciências Biomédicas / USP Aprovada pela Comissão Nacional de Ética em Pesquisa - CONEP, em 10 de fevereiro de 1998 
Dedico este trabalho com muito amor e gratídão...

Aos meus pais, Mauro D’Epiro $\mathcal{N}$ etto e María Valéría Soares D'Epiro, pelo apoio, carinho, paciência. Obrígada por tudo, pois tudo que tenho e sou devo a vocês.

$\mathcal{A}$ o meu irmão $\mathcal{M a u r o ~} \mathcal{D}^{\prime}$ Epiro Junior, meu grande amigo acima de tudo, por todos os momentos que me ajudou a superar e acreditar que esta etapa sería cumprída.

Ao meu namorado com muito amor Raphael Coser Dalphorno, pelo incentivo, pela paciêncía e por me dar força nos momentos difíceís.

Vocês souberam entender meus objetivos e me incentivaram para que eu cumprisse com êxito até o final. Sem a presença de cada um de vocês eu não tería conseguido...

Muito obrígada! 


\section{AGRADECIMENTOS}

Agradeço muito a Deus, por ter direcionado o meu caminho ao propósito da realização deste trabalho.

Agradeço a Universidade de São Paulo, sempre com admiração e respeito.

Agradeço em especial a minha orientadora Profa. Dra. Marcía Pinto $\mathcal{A}$ lves Mayer, primeiramente por ter aberto com tanto carinho as portas de seu laboratório e sempre servirá de exemplo em meu futuro, motivando-me na pesquísa científica e mostrando-me o que é ser um professor firme, capaz, integro e principalmente uma grande amiga.

Agradeço com muito carinho e admíração minha grande amiga e irmã mais velha Silvia Regina Loureiro Teixeira, por ter me ajudado em todos os momentos fáceis e difíceis deste trabalho e acima de tudo por toda amizade e carinho. Com certeza se não fosse sua presença, eu nunca tería conseguido termínar minha dissertação.

Agradeço com carinho e respeito a minha eterna professora Príscila Larcher Longo, por todos os ensinamentos durante a graduação e principalmente por ter guiado meus passos até o laboratório de microbiologia oral, mas principalmente por ter incentivado meu amor por microbiología. 
Agradeço a Profa. Dra. Marinilce Fagundes dos Santos por todos os ensinamentos durante a iniciação cientifica, por toda a amizade e por incentivar meu amor a pesquisa cientifica.

Agradeço com eterna gratídão a Profa. Dra. Andrea da Síva Bredariol por ter guiado meus caminhos a pesquisa cientifica.

Agradeço por toda a ajuda e apoío técníco do Léo e João Paulo.

Agradeço com muito carinho meus amigos do laboratórío de mícrobiologia oral, Adriana, Carol, Cris, Didi, Ellen, Éricka, Flavia, Glaucia, Josely, Juliana, Líliane, Lucas, Maike, Mouna, Pamela, Regiane, pela ajuda e amizade. Vocês tornaram minha caminhada mais leve e me mostraram o valor da amizade.

Agradeço a Profa. Dra. María Regina Lorenzettí Simionato e aos amigos Andrea, Dani, Grazi, Luciana e Paulo por toda ajuda e principalmente por possibilitarem o termino deste trabalho cedendo um espaço na câmara de anaerobiose.

Agradeço a todos os meus amigos e professores do departamento de microbiologia, principalmente as minhas amigas Heloisa e Aline, por todo o apoio durante o mestrado.

Agradeço as secretárias Aninha, Naide, Alice e ao secretário Bruno, pelo suporte e compreensão nos momentos difíceis. 
Agradeço ao Henri Berghs e Rubens Duarte (Instituto de Oceanografia) por toda a ajuda com o Bionumerics possibilitando maior facilidade na análise dos resultados desta dissertação.

Agradeço a Vanessa Naomi por toda a ajuda no serviço de seqüenciamento.

Agradeço a María do Carmo por toda a ajuda com o comitê de étíca.

Agradeço a Rosana Prísco pela ajuda na análíse estatístíca do trabalho.

Agradeço a todos os amigos e professores da FIG por todo incentivo e por todos os ensinamentos durante a graduação.

Agradeço com muito carínho e admiração minha avó María, meu vozinho José e minha avó Hosana, por todo carinho e incentivo.

Agradeço a minha madrinha, minha prima Liz, meus prímos, meus tios e tías, por todo carinho e incentivo.

Agradeço a Fundação de Amparo à Pesquisa do Estado de São Paulo (FAPESP) pelos recursos concedidos para a realização deste trabalho

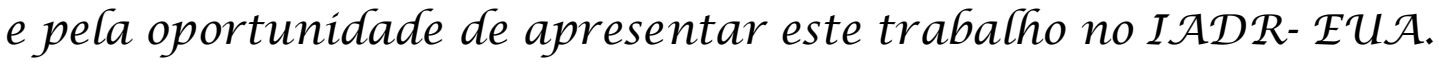

$\mathcal{A}$ todos que colaboraram e me ajudaram a realizar este trabalho O meu sincero agradecimento! 


\section{O sonho}

Sonhe com aquilo que você quer ser, porque você possui apenas uma vída

e nela só se tem uma chance de fazer aquilo que quer.

Tenha felicidade bastante para fazê-la doce.

Dificuldades para fazê-la forte.

Tristeza para fazê-la humana.

E esperança suficiente para fazê-la feliz.

As pessoas maís felizes não têm as melhores coísas. Elas sabem fazer o melhor das oportunidades que aparecem em seus caminhos.

$\mathcal{A}$ felicidade aparece para aqueles que choram.

Para aqueles que se machucam

Para aqueles que buscam e tentam sempre.

E para aqueles que reconhecem

a importância das pessoas que passaram por suas vídas.

Clarice Lispector 
Este trabalho foi financiado pela Fundação de Amparo à

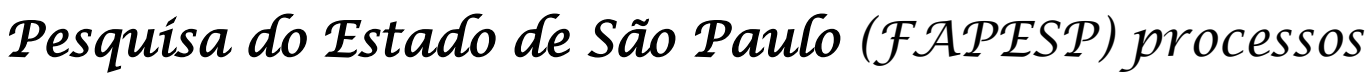
número: 2009/13029-1 e 2009/53958-1 


\section{RESUMO}

D'EPIRO, T. T. S. Estrutura populacional, características fenotípicas e variabilidade do lócus de síntese do polissacarídeo capsular de amostras de Porphyromonas gingivalis. 2011. 78 f. Dissertação (Mestrado em Microbiologia) Instituto de Ciências Biomédicas, Universidade de São Paulo, São Paulo, 2011.

Porphyromonas gingivalis é um dos principais organismos associados à periodontite crônica e apresenta intensa diversidade, que poderia refletir em sua virulência. A maioria dos estudos sobre a virulência de $P$. gingivalis foi realizada com cepas de referência, e pouco se conhece sobre este aspecto em isolados clínicos. A capacidade de indução de abscessos difusos em modelos animais experimentais parece estar associada a cepas capsuladas, enquanto a expressão de fímbrias e a capacidade de internalização em células epiteliais não fagocíticas, foram relacionadas à cepa não capsulada. Em $P$. gingivalis, o lócus de biossíntese do polissacarídeo capsular (BPC) apresenta características de ter sido adquirido por transferência horizontal de genes. O objetivo do presente estudo foi testar a hipótese de que a estrutura populacional de $P$. gingivalis relaciona-se com a variabilidade do lócus BPC e características fenotípicas como produção de cápsula e hidrofobicidade. Foram analisadas 28 cepas de $P$. gingivalis pertencentes aos 5 genótipos fimA quanto a, presença da cápsula por microscopia óptica, hidrofobicidade e detecção de genes do lócus BPC por PCR. A análise filogenética foi realizada por tipagem através de seqüenciamento de genes housekeeping (multilocus sequence typing, MLST). Dezesseis entre 28 amostras estudadas apresentaram cápsula, e não foram detectadas diferenças na hidrofobicidade dos isolados clínicos capsulados e não capsulados. O gene pg0106 foi detectado por PCR em $75 \%$ das amostras capsuladas e em $83 \%$ das amostras não capsuladas, enquanto pg0111 foi detectado em apenas $31 \%$ de amostras capsuladas. Apenas um isolado clínico e a amostra padrão W83 foram classificados como $\mathrm{K} 1$, por apresentarem o gene pg0118. Através do MLST foi possível identificar grande variabilidade entre as amostras de P.gingivalis. Foi observada que há tendência de associação entre os genes do lócus BPC e os genótipos fimA ou hidrofobicidade, mas nenhum cluster foi associado à presença da cápsula. Os dados indicam associação entre o lócus BPC e produção de cápsula, porém a diversidade deste lócus parece ser maior do que a relatada na literatura. 
Palavras-chave: Periodontite Crônica. Porphyromonas gingivalis. Fatores de virulência. Cápsula. 


\begin{abstract}
D'EPIRO, T. T. S. Population structure, phenotypic characteristics and variability of locus of synthesis of the capsular polysaccharide of Porphyromonas gingivalis isolates. 2011. 78 p. Masters thesis (Microbiology) Instituto de Ciências Biomédicas, Universidade de São Paulo, São Paulo, 2011.
\end{abstract}

Porphyromonas gingivalis is one of main organisms associated with chronic periodontitis and is largely diverse, which could reflect in its virulence. Most studies on the virulence of $P$.gingivalis were performed with reference strains, and little is known about this aspect in clinical isolates. The ability to induce diffuse abscesses in experimental animal models seems to be associated with encapsulated strains, while expression of fimbriae and the ability to internalize into non phagocytic epithelial cells were related to noncapsulated strains. In P.gingivalis, the locus of biosynthesis of the capsular polysaccharide (GP) has characteristics of having been acquired by horizontal gene transfer. This study aimed to test the hypothesis that the structure population of $P$.gingivalis is related to the variability of the GPC locus and phenotypic characteristics such as capsule production and hydrophobicity. 28 P.gingivalis isolates representing fimA genotypes were screened for presence of capsule by light microscopy, hydrophobic properties and detection of genes in the GPC locus by PCR. The phylogenetic analysis was performed by sequencing of housekeeping genes typing (multilocus sequence typing, MLST). Sixteen of 28 studied samples had capsule, and there were no differences in the hydrophobic properties of capsulated and non capsulated clinical isolates. The pg0106 gene was detected by PCR in $75 \%$ of capsulated isolates and in $83 \%$ of not capsulated while pg011 was detected in only $31 \%$ of encapsulated isolates. One clinical isolate and reference strain W83 were classified as $\mathrm{K} 1$, due to the presence of pg0118 gene. MLST detected large variations within the P.gingivalis population. MLST clustering analysis revealed a relation between sequence type (STs) and fimA genotype or hydrophobic property and genes encoding for the biosynthesis of capsular polysaccharide, but there was no association of STs with the presence of capsule. The data indicated an association between GPC locus and capsule production but the diversity of this locus appeared to be greater than that reported in the literature. 
Keywords: Chronic Periodontitis. Porphyromonas gingivali. Virulence factors. Capsule. 


\section{LISTA DE ILUSTRAÇÕES}

Figura 1- Esquema representando o locus genético da biossíntese do polissacarídeo capsular em Porphyromonas gingivalis W83. A seta de cor verde representa o gene presente nas cepas ATCC 33277 (não capsulada) e W83 (capsulada). As setas cinza representam os genes encontrados somente na cepa W83. Em amarelo o gene presente somente nas cepas $\mathrm{K} 1$.

Figura 2- Microfotografia de células de $P$. gingivalis após coloração de Hiss. (A) W83: A seta aponta a célula bacteriana corada e cápsula com coloração negativa. (B) ATCC33277, ausência de cápsula.

Figura 3- Análise da prevalência de cepas capsuladas e não capsuladas de $P$.gingivalis através de porcentagem

Figura 4- Gráfico representando os valores de mediana, quartil superior e inferior, e desvio padrão da porcentagem de células aderidas ao nhexadecano (hidrofobicidade) em amostras capsuladas e não capsuladas de P.gingivalis. Teste estatístico de Mann-Whitney -

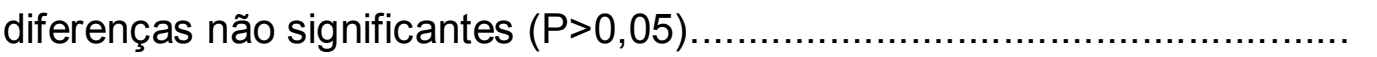

Figura 5: Fotografia de gel de agarose $1 \%$ corado com brometo de etídio onde os amplicons da reação de PCR para detecção do gene pg106 foram submetidos a corrida eletroforética em tampão TAE. PM: marcador de peso molecular $1 \mathrm{~Kb}$. Produto de amplificação utilizando como molde DNA das amostras clínicas. Em 1. Alfa, em 2: 6 26, em 3: ATCC 33277, em 4: W83, em 5: controle negativo. Observa-se produto de cerca de 1150 pb resultado da amplificação do gene pg0106 apenas nas canaletas 2,3 , e 4

Figura 6- Distribuição das cepas de P.gingivalis de acordo com a presença de cápsula e detecção do gene pg0106 por PCR.

Figura 7: Fotografia de gel de agarose $1 \%$ corado com brometo de etídio onde os amplicons obtidos na reação de PCR para o gene pg0111 foram submetidos a corrida eletroforética em tampão TAE. PM: marcador de peso molecular $1 \mathrm{~Kb}$. Produto de amplificação utilizando como molde DNA das amostras clínicas em: 1. 279C1, em 2. 275C4, em 3: ATCC 33277, em 4: 9C, em 5:324A4, em 6: P9/86, 7: controle positivo (W83), 8: controle negativo. Observa-se produto de amplificação de 
1250 pb resultado da amplificação do gene pg111 nas canaletas 4,5,6 e 7 (controle positivo).

Figura 8- Distribuição de cepas de P.gingivalis de acordo com a presença de cápsula e deteç̧ão do gene pg0111 por PCR

Figura 9: Fotografia de gel de agarose $1 \%$ corado com brometo de etídio onde os amplicons da reação de PCR para o gene pg0118 foram submetidos a corrida eletroforética em tampão TAE. PM: marcador de peso molecular $1 \mathrm{~Kb}$. Produto de amplificação utilizando como molde DNA das amostras clínicas em: 1. 279C1, em 2. 381B, em 3: beta, em 4: HW, em 5: 259C3, em 6: 9C, 7: controle negativo, 8: controle positivo (W83). Observa-se produto de amplificação de $1.050 \mathrm{pb}$ resultado da amplificação do gene pg118 apenas nas canaletas 6 e 8 (controle positivo).

Figura 10- Distribuição de cepas de $P$. gingivalis de acordo com a presença de cápsula e detecção do gene pg0118 por PCR.

Figura 11- Dendrograma baseado no coeficiente de similaridade DICE através do método algorítimo UPGMA, mostrando o padrão de similaridade de 25 cepas de $P$. gingivalis. A barra superior indica a porcentagem de similaridade entre cepas. Os dados foram comparados ao genótipo fimA, a presença de cápsula, aos genes do polissacarídeo capsular e a porcentagem de hidrofobicidade 


\section{LISTA DE TABELAS}

Tabela 1- Isolados clínicos de P.gingivalis utilizados no estudo, e genótipo fimA.

Tabela 2- Iniciadores utilizados para análise do lócus de biossíntese de polissacarídeo capsular.

Tabela 3- Seqüências dos iniciadores utilizados na análise por MLST para amplificação de diferentes genes cromossomais, tamanho do produto, as diferentes temperaturas de anelamento e a função de cada gene.

Tabela 4- Valores de média, mediana e desvio padrão da porcentagem de células que permaneceram aderidas ao n-hexadecano em relação ao valor inicial (hidrofobicidade) de amostras de P.gingivalis capsuladas e não-capsuladas

Tabela 5- Número dos alelos e sequence typing (STs) das amostras analisadas através de MLST.Observa-se que foram encontrados alguns alelos que não foram descritos no banco de dados $\left(^{*}\right)$ e STs que também não foram descritas $\left({ }^{* *}\right)$.

Tabela 6- Número de alelos previamente identificados no banco de dados, número de alelos primeiramente detectados neste estudo (alelos novos) e número total de alelos para cada gene determinados por MLST em amostras de $P$. gingivalis.

Tabela 7- Número de amostras de P.gingivalis classificadas quanto ao genótipo fimA, produção da cápsula, genes do polissacarídeo capsular e hidrofobicidade divididas em diferentes grupos através da análise do dendrograma da técnica MLST. 


\section{LISTA DE ABREVIATURAS E SIGLAS}

$\mu \mathrm{g}$ - micrograma

$\mu \mathrm{l}-$ microlitro

AP-PCR- Reação de Polimerase em Cadeia com Primer Arbitrário

ATCC- American Type Collection

bp - pares de base

BPC- principal locus do polissacarideo capsula

BS-HM- Agar Brucella sangue suplementado com hemina e menadione dNTP- desoxirribonucleotídeos trisfosfato

DO- densidade óptica

EDTA - ácido etilenodiamino tetra-acético

fimA- gene que codifica a fimbrilina de Porphyromonas gingivalis

g-grama

G+C- Conteúdo de guanina e citosina

IFNY- Interferon Y

IL-1 $\beta$ - Interleucina- $1 \beta$

IL-6- Interleucina- 6

IL-8- Interleucina-8

K- Antigeno capsular

$\mathrm{K}^{-}$- Ausência de antígeno capsular

LPS- lipopolissacarídeo

mg - miligrama

min - minuto

$\mathrm{ml}$ - mililitro

MLEE- eletroforese de enzimas multilocus

MLST- multilocus sequence typing (tipagem por seqüenciamento de multilocus)

$\mathrm{mM}$ - milimolar

ng - nanograma

nm - nanômetro

NT- amostra não tipável

PCR - Reação em cadeia da polimerase

PFGE- pulsed-field gel eletrophoresis (eletroforese em campo pulsado) 
PM- peso molecular

pM - picomolar

RAPD- Análise de DNA polimórfico amplificado randomicamente

rpm - rotações por minuto

STs- Sequence type

TAE - Tris acetato EDTA

Taq DNA polimerase- DNA polimerase termoestável de Thermus aquaticus.

TE - Tris EDTA

TSB-HM Caldo Tripticase Soja suplementado com hemina e menadione. 


\section{SUMÁRIO}

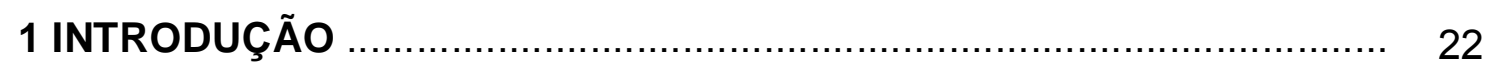

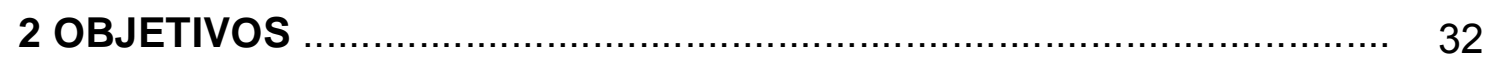

3 MATERIAL E MÉTODOS ............................................................ 33

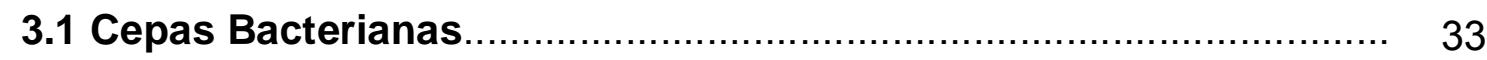

3.2 Determinação de características fenotípicas.................................... 35

3.2.1 Detecção a produção de cápsula por microscopia óptica............. 35

3.2.2 Ensaio de Hidrofobicidade ...................................................... 36

3.3 Detecção do lócus de síntese de polissacarídeo capsular e do sorotipo K1 por PCR....................................................................... 37

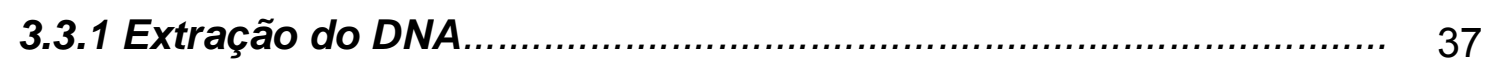

3.3.2 Caracterização do lócus de biossíntese de polissacarídeo capsular (BPC) e detecção do genótipo K1..................................... 37

3.3.3 Determinação da estrutura populacional por MLST ...................... 39

4 RESULTADOS

4.1 Detecção da produção de cápsula por microscopia óptica.............. 41

4.2 Ensaio de hidrofobicidade .................................................... 42

4.3. Detecção do lócus de síntese de polissacarídeo capsular e do sorotipo K1 por PCR......................................................................... 44

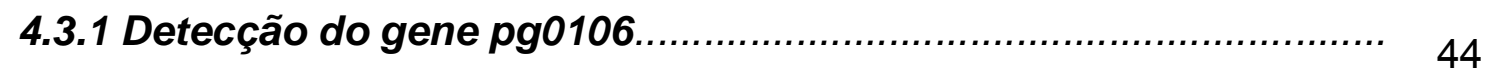

4.3.2 Detecção do gene pg0111...................................................... 46

4.3.3 Detecção do gene pg0118................................................. 48

4.4 Determinação da estrutura populacional por MLST ......................... 49

5 DISCUSSÃO

6 CONCLUSÕES

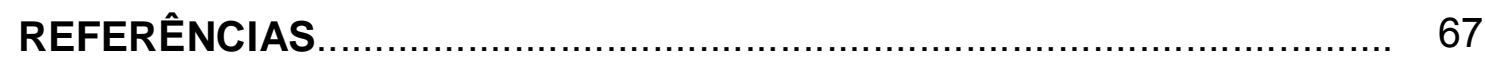




\section{INTRODUÇÃO}

A periodontite crônica é um processo inflamatório que leva a reabsorção óssea, migração apical do epitélio juncional e perda dos dentes, sendo resultado da interação entre bactérias presentes no biofilme subgengival e os tecidos do hospedeiro (HAFFAJEE e SOCRANSKY, 1994; SOCRANSKY et al., 1998; HOLT e EBERSOLE, 2005; HAFFAJEE e SOCRANSKY, 2005). A periodontite é uma das patologias bucais mais prevalentes no mundo, e tem sido estimado que afeta cerca de $25 \%$ da população adulta mundial, enquanto $5-6 \%$ dos indivíduos apresentam periodontite severa (BARNARD, 1993; OLIVER et al., 1998; PATHIRANA et al., 2010). A periodontite pode estar associada a doenças cardiovasculares, nascimentos prematuros e recentemente foi descrita a sua associação com artrite reumatóide (BECK et al., 1996; DAVENPORT et al., 2002; LIAO et al., 2009). Apesar de mais de 700 espécies/filotipos bacterianos terem sido descritos na cavidade bucal, apenas um pequeno número de espécies foi associado com a periodontite crônica até o momento (PASTER et al., 2001; BYRNE et al., 2009).

Não somente a composição da microbiota influencia na severidade da doença periodontal, mas também fatores inerentes ao hospedeiro poderiam induzir a progressão da doença, como o tabagismo. Tem sido descrito que fumantes usuários de tabaco são mais susceptíveis a infecções por patógenos periodontais, já que o tabaco pode alterar a ecologia do ambiente oral, além de alterar a resposta imune (BAGAITKAR; DEMUTH; SCOTT, 2008; BAGAITKAR et al., 2010). Assim, os fumantes apresentam maior perda óssea e dentária e maior índice de sangramento a sondagem e edema (SCOTT e SINGER, 2004; NATO et al., 2005; PALMER et al., 2005; BAGAITKAR et al., 2010).

As bactérias da placa subgengival co-habitam em complexos (SOCRANSKY et al., 1998), sendo que foram descritos 5 complexos bacterianos principais no ambiente subgengival, de acordo com a relação entre diferentes espécies, denominados complexos vermelho, laranja, amarelo, verde e roxo.

Estudos transversais e longitudinais analisando a microbiota subgengival de pacientes com diferentes condições periodontais e fatores de virulência dos organismos do biofilme formaram as evidências que implicaram organismos do denominado complexo vermelho, Porphyromonas gingivalis, Treponema denticola 
e Tannerella forsythia, como os principais patógenos associados com a periodontite crônica (SLOTS et al., 1986; DARVEAU et al., 1997; SOCRANSKY et al., 1998; AMANO, 2003; HOLT e EBERSOLE, 2005).

$P$. gingivalis é um cocobacilo, Gram negativo, assacarolítico, anaeróbio estrito e imóvel. Em um ambiente limitado de hemina, apresenta baixa capacidade de virulência, como demonstrado em modelo animal (MCKEE et al., 1986; VAN WINKELHOFF et al., 1988; HOLT et al., 1999; PATHIRANA et al., 2010). Esta espécie está presente, em altos níveis, em sítios periodontais com sangramento à sondagem e supuração (SLOTS, 1999; CHEN et al., 2002; EGLAND; PALMER JR; KOLENBRANDER, 2004). No entanto, $P$. gingivalis pode também ser detectada em baixas proporções no biofilme de indivíduos sem perda de inserção clínica, sendo reconhecida como parte da microbiota normal (HAFFAJEE et al., 1998; MISSAILIDIS et al., 2004; LEDDER et al., 2007). P. gingivalis, juntamente com $T$. denticola e $T$. forsythia são considerados colonizadores tardios do biofilme subgengival, colonizando principalmente a região próxima ao epitélio interno da bolsa periodontal. Estas espécies dependem da colonização prévia do biofilme por microrganismos pioneiros, e de colonizadores intermediários, como Fusobacterium nucleatum e Micromonas micros (SOCRANSKY e HAFFAJEE, 2005).

$P$.gingivalis apresenta um grande número de fatores de virulência que incluem o lipopolissacarídeo (LPS), polissacarídeo capsular, fímbrias, hemaglutinina e enzimas proteolíticas extracelulares, propiciando a adesão aos tecidos orais, formação de biofilme, indução do quadro inflamatório, obtenção de nutrientes e evasão das defesas do hospedeiro (LAMONT e JEKINSON, 1998; LAMONT e JEKINSON, 2000). Entretanto, há evidências que componentes do tabaco podem aumentar a virulência de P.gingivalis (SAYERS et al., 1997; BAGAITKAR et al., 2010).

Este patógeno oportunista pode invadir células não fagocíticas e se multiplicar no citoplasma, e sua sobrevivência no interior da célula poderia estar associada à manutenção da cronicidade da lesão periodontal (LAMONT et al., 1995; PARK et al., 2004; MAO et al., 2007). A localização intracelular propicia que o patógeno escape do sistema imune do hospedeiro e da ação de antibióticos, levando à multiplicação e disseminação aos tecidos adjacentes.

A apoptose, ou morte celular programada, é um importante processo biológico utilizado pelos organismos multicelulares para eliminar células infectadas 
manmtendo desta maneira o desenvolvimento normal, integridade e homeostase do organismo (HENGARTNER et al., 2000). Estudos in vitro mostraram que $P$. gingivalis pode induzir a apoptose de fibroblastos, linfócitos, células endoteliais e epiteliais da gengiva (URNOWEY et al., 2006; ROTH et al., 2007; STATHOPOULOU et al., 2009). Por outro lado, existem estudos que relatam a inibição do processo apoptótico de células eucariontes por P.gingivalis (HIROI et al., 1998; NAKHJIRI et al., 2001; YILMAZ et al., 2004; MAO et al., 2007). Os resultados discrepantes entre estudos sugerem que quando 0 rateio bactérias/células epiteliais é baixo e o tempo de exposição é curto, ocorre invasão bacteriana, o que resulta em inibição do processo apoptótico. Por outro lado, quando a quantidade de bactérias e o tempo de exposição aumentam, pode ocorrer a apoptose (STATHOPOULOU et al., 2009).

As fímbrias são componentes filamentosos distribuídos sobre a superficie celular de P.gingivalis (SUGANO et al., 2004) e são consideradas potentes fatores de virulência por participarem da adesão da bactéria. O gene fimA, que codifica a fimbrilina, a subunidade protéica da fímbria (HOLT et al., 1999; YILMAZ et al., 2002), foi classificado em 6 tipos baseados na sequência de nucleotídeos denominados: tipo I, tipo Ib, tipo II, tipo III, tipo IV e tipo V (LEE et al., 1991; AMANO et al., 1999; NAKAGAWA et al., 2002).

A internalização de $P$. gingivalis em células epiteliais gengivais envolve um processo coordenado de adesão e invasão, mediado pelas fímbrias, pela produção de gingipaína e por uma variedade de proteínas de superfície celular (DASHPER et al., 2009) que manipulam as vias de sinalização celular, favorecendo a permanência intracelular (HASEGAWA et al., 2008). No entanto, nem todas as cepas desta espécie expressam a fímbria. A amostra ATCC 33277 é fimbriada e altamente invasiva em células epiteliais em cultura (DUNCAN; NAKAO; XIE, 1993; LAMONT e JENKINSON, 2000; UMEDA et al., 2006) e induz a formação de abscessos localizados em modelos animais experimentais. Por outro lado, as amostras de $P$. gingivalis consideradas de maior virulência em modelos experimentais em animais, capazes de induzir a formação de abscessos difusos, como as cepas W83 e W50, são capsuladas e não expressam a fímbria (GRENIER e MAYRAND, 1987; NEIDERS et al., 1989; LAINE e VAN WINKELHOFF, 1998; YOSHIMURA et al., 2008). 
Existe variabilidade no gene $\operatorname{fim} A$, que codifica a subunidade da fímbria principal, a fimbrilina, sendo relatados 6 genótipos fimA baseado na diversidade do gene, além da existência de cepas não tipáveis (AMANO et al., 2004; UMEDA et al., 2006). Apesar da maior prevalência do genótipo II no biofilme subgengival de pacientes com periodotite crônica, inclusive no Brasil (MISSAILIDIS et al., 2004), estudos em nosso laboratório demonstraram que as cepas deste genótipo não são mais invasivas que as demais (UMEDA et al., 2006). Outros estudos confirmaram a ausência de relação entre o genótipo $\operatorname{fim} A$ de $P$. gingivalis e o processo de invasão em células epiteliais, demonstrando que a atividade de gingipaína é associada a maior capacidade invasiva da amostra (HASEGAWA et al., 2003; INABA et al., 2008).

Em bactérias gram-negativas, a cápsula de natureza polissacarídica apresenta um importante papel na manutenção da integridade estrutural da célula em um ambiente hostil, atuando como um reservatório de água e nutrientes. Além disso, é uma importante barreira para o reconhecimento do sistema imune do hospedeiro, reduzindo a opsonisação e favorecendo a resistência à fagocitose por leucócitos (BOTTA et al., 1994; ADUSE-OPUKO et al., 2006).

A cápsula exerce um importante papel na virulência de vários patógenos e sua expressão pode ser regulada pelas condições de cultivo (WRIGHT et al., 1999; HILTON et al., 2006). Estudos in vitro com cepas capsuladas de Staphylococcus aureus mostraram que a cápsula pode modular a adesão a células endoteliais e estudos in vivo relataram que esta estrutura é importante para a colonização pela bactéria na em superfícies mucosas. Além disso, a cápsula impedi a fagocitose possibilitando que este patógeno sobreviva na corrente sanguínea (LEE e LEE 199; O'RIORDAN e LEE, 2004).

Em $P$. gingivalis, a presença da cápsula também está relacionada ao menor reconhecimento pelo sistema de defesa do hospedeiro. A presença da cápsula resulta em menor nível de transcrição dos genes que codificam interleucina-1 $\beta$ (IL-1 $\beta$ ), interleucina-6 (IL-6) e interleucina-8 (IL-8) em fibroblastos, sugerindo que a cápsula atua como interface entre o patógeno e o hospedeiro, reduzindo a resposta pró-inflamatória, favorecendo a sobrevivência do patógeno (BRUNNER et al., 2010). Por outro lado, a capacidade de induzir apoptose em células epiteliais gengivais, independe da produção de cápsula (STATHOPOULOU et al. , 2009). 
O polissacarídeo capsular pode ser um potente imunógeno, induzindo a resposta protetora, sendo empregado como antígeno em vacinas contra uma série de patógenos como Streptococcus pneumoniae, Staphylococcus aureus Haemophilus influenza e Neisseria meningitidis (PELTOLA, 1998; TOLLERSRUD et al., 2001; BERRY et al., 2002; DAGAN et al., 2004; OVODOV et al., 2006; MOSCOSO e GARCIA, 2009). A infecção experimental em animais com as cepas capsuladas de $P$. gingivalis, como W83, induz a produção de anticorpos séricos contra o antígeno capsular (antígeno K) (VAN WINKELHOFF et al., 1993). O soro com altos títulos de anticorpos contra o antígeno capsular de $P$. gingivalis é capaz de impedir a perda óssea alveolar em animais experimentais infectados por esta espécie (KATZ; WARD; MICHALEK, 1996). Foi também demonstrado que uma vacina baseada no antígeno capsular de $P$. gingivalis é protetora, levando a ausência de perda óssea alveolar induzida pela infecção experimental pela bactéria (GONZÁLES et al., 2003). No entanto, em várias espécies pode ocorrer variabilidade no antígeno capsular, favorecendo a sobrevivência de patógenos. A produção de cápsula por Bacteroides fragilis é essencial para que ocorra a colonização do intestino, e a síntese de diferentes polissacarídeos capsulares pela mesma amostra confere maior capacidade de sobrevivência neste ambiente complexo e competitivo (KRINOS et al., 2001; CHATZDAKI et al., 2008).

Foram descritos seis sorotipos capsulares $(\mathrm{K} 1-\mathrm{K} 6)$ em $P$. gingivalis e um sétimo foi sugerido (BRUNNER et al., 2008). Porém, pouco se conhece sobre a prevalência de cepas capsuladas e dos diferentes sorotipos capsulares de $P$. gingivalis. A análise da resposta de anticorpos séricos contra os seis antígenos capsulares (K1 - K6), em pacientes com periodontite e pacientes saudáveis, revelou que ocorre forte resposta de anticorpos apenas contra os antígenos $\mathrm{K} 1$ (relativo a cepas W50 e W83) e K6, e não contra os demais sorotipos (SIMS et al., 2001), sugerindo que $P$. gingivalis $\mathrm{K} 1$ e $\mathrm{K} 6$ seriam mais prevalentes entre pacientes com periodontite. Por outro lado, é possível que estes antígenos capsulares sejam mais imunogênicos que os demais. Análise em outras populações mostrou que anticorpos contra todos os antígenos $\mathrm{K}$ foram encontrados nos soros de pacientes com doença periodontal (ADUSE-OPOKU et al., 2006), sugerindo diferenças na prevalência dos antígenos capsulares de $P$. gingivalis entre populações. 
Griffen et al. (1999), analisando isolados clínicos através de tipagem por análise de heteroduplex da região intergênica rRNA (ISR), demonstraram que cepas de $P$. gingivalis similares às cepas capsuladas W83 e W50, estavam mais associadas à periodontite severa do que outros tipos. É interessante notar que as cepas W83 e W50 apresentam o genótipo fimA IV, baseado no gene que codifica a fímbria principal, fimA, embora estas não expressem a fímbria principal (YOSHIMURA et al., 2008). Em estudo realizado neste laboratório foi demonstrado que os níveis subgengivais do genótipo $\operatorname{fimA}$ IV, mas não do genótipo II se relacionavam com a profundidade de sondagem em pacientes fumantes com periodontite crônica (TEIXEIRA et al., 2009), sugerindo maior virulência de determinadas linhagens.

Estudos com microarranjos comparando o genoma completo das cepas W83 e ATCC 33277 mostraram divergências em genes organizados no operon codificando enzimas envolvidas na síntese do polissacarídeo capsular (lócus BPC), e em outro cluster apresentando de maneira similar ao lócus BC, menor conteúdo $\mathrm{G}+\mathrm{C}(41 \%)$ do que o genoma completo (48\%), sugerindo que estas regiões foram adquiridas por transferência horizontal (CHEN et al., 2004).

A região PG0106-PG0120 (lócus BPC) do genoma de W83 caracteriza o lócus de síntese do polissacarídeo capsular (CHEN et al., 2004). Outros três lócus podem ser associados com a síntese do polissacarídeo capsular, PG1135PG1142, PG0435-PG0437 e PG1560-PG1565, apesar dos lócus PG0435-PG0437 e PG1560-PG1565 serem possivelmente insuficientes para codificar a maquinaria de biossíntese capsular (ADUSE-OPOKU et al., 2006). A análise do lócus BPC revelou a presença de genes que codificam quatro glicosiltransferases (PG0106, PG0111, PG0118, PG0119) e uma serina acetiltransferase (PG0115) (ADUSEOPOKU et al., 2006). Além disso, a região PG1135-PG1142, que codifica múltiplas glicosiltransferases e produtos envolvidos com a exportação de polímeros, é considerada conservada entre as cepas de $P$. gingivalis de diferentes sorotipos capsulares (NELSON et al., 2003; ADUSE-OPOKU et al., 2006).

A cepa $P$. gingivalis ATCC 33277 não possui parte da região PG0106PG0120 (Figura 1), apesar de apresentar o gene PG0106 do genoma de W83 codificando um produto com $98 \%$ de identidade de aminoácidos. No entanto, o gene putativo da biossíntese de polissacarídeo capsular (pg0111) de W83 não 
encontra homólogo em ATCC 33277 (CHEN et al., 2004; DAVEY e DUNCAN 2006; TACHIBANA-ONO et al., 2008).

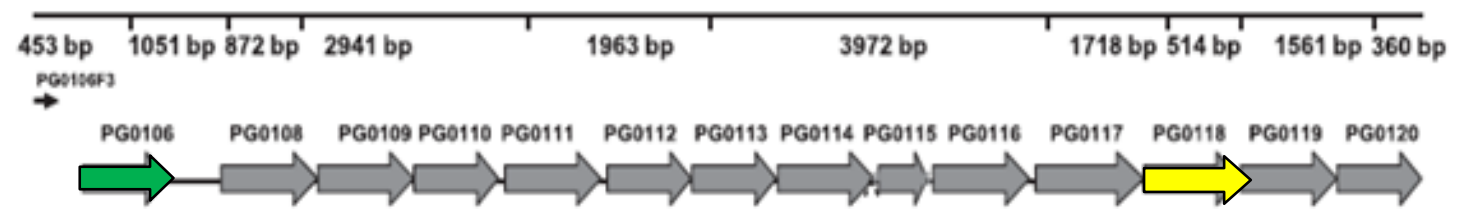

Figura 1 - Esquema representando o locus genético da biossíntese do polissacarídeo capsular em Porphyromonas gingivalis W83. A seta de cor verde representa o gene presente nas cepas ATCC 33277 (não capsulada) e W83 (capsulada). As setas cinza representam os genes encontrados somente na cepa W83. Em amarelo o gene presente somente nas cepas K1

Fonte: modificada de Brunner et al., 2008.

Mutantes por deleção nas regiões PG0106 a PG0120 e PG109 - PG118 na cepa $P$. gingivalis W50 resultaram em cepas não capsuladas, porém, mutantes por inserção na flipase pg0117 são capsuladas (ADUSE-OPOKU et al., 2006). O sequenciamento do lócus BPC na cepa 381 (não capsulada) revelou diferenças como troca de PG0109-PG0110 por três ORFS distintas e deleção de PG0112PG0114 (CHEN et al., 2004).

Além disso, estudos com RFLP mostraram que há uma grande variação no lócus PG0106-PG0120 entre os sorotipos (BRUNNER et al., 2008). Têm sido relatadas poucas diferenças na capacidade de virulência de cepas de diferentes sorotipos capsulares, sendo que todos os sorotipos capsulares são capazes de induzir resposta imunológica por macrófagos (VAN WINKELHOF et al., 1993; LAINE et al.,1996; LAINE e VAN WINKELHOFF, 1998; BRUNNER et al., 2010). Apesar da presença de cápsula ser associada à indução de abscessos difusos em modelos animais, além da cápsula, possivelmente outros determinantes de virulência poderiam participar do processo, pois foram detectados comportamentos distintos na indução de abscessos experimentais entre cepas de um mesmo sorotipo capsular (NEIDERS et al., 1989).

Diferenças na virulência entre amostras de diferentes sorotipos $\mathrm{K}$ podem ser atribuídas à interação com o sistema imune, já que o polissacarídeo capsular é um potente imunógeno, pois, ratos imunizados com polissacarídeo capsular purificado de $P$. gingivalis A7436 (K1) apresentaram elevados títulos de lgM e IgG contra esta bactéria e foram protegidos contra perda óssea alveolar quando 
desafiados com bactérias vivas (CHOI et al., 1998; GONZALEZ et al., 2003). Células dendríticas infectadas com cepas de diferentes sorotipos capsulares de P.gingivalis, apresentaram comportamento distinto, sendo que as células infectadas com cepas do sorotipo K1 e K2 expressaram maiores níveis de IL-1 $\beta$, IL-6, IL-12, IL-12 e IFNy, do que as infectadas com outros sorotipos K3-K6 e K-. Além disso, cepas dos sorotipos K1 e K2 são mais resistentes a fagocitose e morte por leucócitos que as demais (SUNDQVIST et al., 199; VERNAL et al., 2009). Foi também relatado que cepas do sorotipo K4 apresentaram maior capacidade de adesão a células epiteliais da bolsa periodontal do que cepas de outros sorotipos (DIERICKX et al., 2003).

Os dados obtidos com um número restrito de isolados sugerem que as amostras não capsuladas podem diferenciar-se das capsuladas pela maior hidrofobicidade, pela habilidade de auto-agregação e maior capacidade de adesão ao epitélio da bolsa e co- agregação a outras bactérias orais (WATANABE et al., 1992; VAN WILKENHOLF et al., 1993; LAINE et al., 1996; DIERICKX et al., 2003). O processo de co-agregação bacteriano pode ser definido como a capacidade de adesão a diferentes espécies bacterianas e difere da auto agregação, que pode ser definida como adesão entre células da mesma espécie bacteriana (KOLENBRANDER et al., 1988; KINDER et al., 1994). Assim, tanto a capacidade de autoagregação de $P$. gingivalis como a sua co-agregação com $F$. nucleatum podem ser influenciadas pela expressão de cápsula. Estes processos influenciam não apenas na formação do biofilme dental, mas na manifestação da patogenicidade, pois a interação entre P.gingivalis e F.nucleatum também foi relacionada à formação de abscesso subcutâneo (BAUMGARTNER et al., 1992; FEUILLE et al., 1996).

A expressão de fímbrias é associada à formação de biofilmes por P.gingivalis (KUBONIWA et al., 2009). Assim, o uso de agentes que alterem a expressão gênica, como extrato de tabaco, induz a aumento da formação de biofilme por $P$. gingivalis, associado à redução da expressão de cápsula (BAGAITKAR et al. , 2010).

Assim, as evidências aqui apresentadas sugerem que a diversidade fenotípica e genotípica de $P$.gingivalis tem reflexo no potencial de virulência e conseqüentemente na sua capacidade de destruição periodontal (GRIFFEN et al., 
1999; AMANO et al., 2001). Portanto, métodos de tipagem molecular poderiam ser aplicados visando a definição de linhagens de maior virulência em $P$. gingivalis.

Os principais métodos de tipagem através da análise de DNA utilizados para a caracterização de P.gingivalis, são eletroforese em gel de campo pulsadoPFGE (pulsed-field gel eletrophoresis) e tipagem por seqüenciamento de multilocus-MLST (multilocus sequence typing). Em P. gingivalis, PFGE foi utilizado para investigar a transmissão da bactéria entre casais, porém, esta técnica pode oferecer dificuldade de comparação entre os resultados de diferentes laboratórios, além de analisar o perfil de bandas anônimas e não permitir a análise filogenética (ASANO et al., 2003; COOPER e FEIL, 2004). O MLST propicia a comparação entre resultados de diferentes laboratórios através de um banco de dados e tem sido utilizado na determinação de linhagens associadas à virulência em vários patógenos como Neisseiria meningitidis, Campylobacter jejuni, Helicobacter pylori e Escherichia coli (KOEHLER et al., 2003), e tem sido empregado para monitorar os efeitos dos programas de vacinação (VAN LOO et al., 2002).

O MLST (MAIDEN et al., 1998) baseia-se na análise de sequências aproximadamente 450 pb de 7 a 10 genes de manutenção (housekeeping) nos quais é possível identificar variações alélicas e determinar a diversidade genética da população de interesse (MAIDEN et al., 1998; COOPER et al., 2004). Estudos empregando MLST (FRADSEN et al., 2001) sugerem que a recombinação predomina sobre as mutações na espécie (panmixia com predomínio de certas cepas epidêmicas). Por outro lado, foi demonstrada a existência de linhagens de $P$. gingivalis, sendo que o mesmo genótipo fimA está distribuído em linhagens distintas apesar de haver associação entre tipos por MLST e fimA (ENERSEN et al., 2008).

Assim, baseados no exposto, formulamos a hipótese de que o lócus de síntese do polissacarídeo capsular estaria restrito a determinadas linhagens de $P$. gingivalis, que reuniriam além da capacidade de síntese da cápsula, outras características comuns, tornando as cepas capsuladas mais virulentas, justificando a associação de certos genótipos com a maior severidade da doença periodontal (TEIXEIRA et al., 2009). Para testar esta hipótese, no presente estudo foram analisadas cepas de $P$. gingivalis classificadas em diferentes genótipos fimA isoladas de pacientes com periodontite crônica ou com gengivite, quanto a detecção 
do lócus de síntese do polissacarídeo capsular e a expressão de cápsula. Foi também analisada a capacidade hidrofóbica dos isolados, visto ser esta reflexo dos componentes expressos na superfície da célula. Estas características foram relacionadas à estrutura populacional determinada por MLST (ENERSEN et al., 2006). 


\section{OBJETIVOS}

Visando contribuir para o entendimento do papel da cápsula na virulência de $P$. gingivalis, o objetivo geral do presente estudo foi testar a hipótese de que a variabilidade do lócus BPC e a estrutura populacional de $P$. gingivalis relacionamse com características fenotípicas.

Os objetivos específicos foram analisar isolados clínicos de $P$. gingivalis de diferentes genótipos fimA quanto a:

- características fenotípicas como produção de cápsula e hidrofobicidade.

- variabilidade do lócus de síntese do polissacarídeo capsular através de PCR

- estrutura filogenética por MLST. 


\section{MATERIAL E MÉTODOS}

\subsection{Cepas Bacterianas}

No presente estudo foram analisadas as cepas de $P$. gingivalis de referencia ATCC 33277 (fimA I, fimbriada e não produtora de cápsula) e W83 (fimA IV, afimbriada e produtora de cápsula tipo K1), e 26 cepas da mesma espécie, provenientes do Japão, Suécia e Brasil, cujo genótipo fimA foi determinado em estudo prévio realizado em nosso laboratório, como descrito na tabela 1 (UMEDA et al., 2006). As amostras clínicas de pacientes do Brasil foram obtidas de pacientes em tratamento nas clínicas da Faculdade de Odontologia da UNICASTELO e da Faculdade de Odontologia da USP. Este estudo foi aprovado pelo Comitê de ética em pesquisa com seres humanos do Instituto de Ciências Biomédicas/ USP (ICB/USP), processo número 903/CEP.

As células de P.gingivalis foram mantidas em criotubos contendo caldo $\mathrm{BH}$ acrescido de $20 \%$ de glicerol em freezer a $-80{ }^{\circ} \mathrm{C}$ (Revco, Asheville, N.C., EUA). A identificação definitiva foi realizada através de PCR, usando iniciadores espécie-específicos homólogos a 16SrRNA de $P$. gingivalis descrito por Amano et al. $(1999,2000)$ [5'TGT AGA TGA CTG ATG TGT AAA ACC 3' e 5'ACG TCA TCC CCA CCT TCC TC 3']. Estas amostras foram utilizadas em outros estudos do nosso laboratório e fazem parte de uma biblioteca do laboratório. 
Tabela 1 - Isolados clínicos de P.gingivalis utilizados no estudo, e genótipo fimA

\begin{tabular}{|c|c|c|c|}
\hline Cepas de $P$. ingivalis & Fonte & \multicolumn{2}{|c|}{ Genótipo fimA } \\
\hline ATCC 33277 & T. Amano, Universidade de Osaka & & 1 \\
\hline HW24D-1 & do Japão & & II \\
\hline 6-26 & & & III \\
\hline HG564 & & & IV \\
\hline W83 & & & IV \\
\hline HNA99 & & & $\mathrm{V}$ \\
\hline $\mathrm{P} 1604$ & M. Wikström, & & II \\
\hline Kdll 865 & Universidade de Goteborg, Suécia & & $\mathrm{NT}^{*}$ \\
\hline KdIII289 & & & $\mathrm{lb}$ \\
\hline $\mathrm{P} 9 / 86$ & & & II \\
\hline $251 \mathrm{C} 2$ & Umeda et al., 2006 & $\overline{I V}$ & Periodontite \\
\hline 259 B1 & Amostras isoladas em São & $\mathrm{lb}$ & Periodontite \\
\hline 324 A4 & Paulo de pacientes com & 1 & Periodontite \\
\hline $261 \mathrm{~A} 1$ & diferentes condições & $\mathrm{lb}$ & Periodontite \\
\hline 268 A1 & periodontais. & IV & Periodontite \\
\hline 268 A2 & & 1 & Periodontite \\
\hline 279 C1 & & V & Periodontite \\
\hline $316 \mathrm{AB}$ & & I & Periodontite \\
\hline $381 \mathrm{~A}$ & & II & Gengivite \\
\hline $381 \mathrm{C}$ & & II & Gengivite \\
\hline $322 \mathrm{C} 2$ & & II & Periodontite \\
\hline $9 \mathrm{C}$ & & IV & Periodontite \\
\hline $241 \mathrm{CD}$ & & $\mathrm{NT}^{*}$ & Periodontite \\
\hline $259 C 3$ & & $\mathrm{lb}$ & Periodontite \\
\hline Beta & & 1 & Periodontite \\
\hline Gama & & 1 & Periodontite \\
\hline Alfa & & $\mathrm{NT}^{*}$ & Periodontite \\
\hline $275 \mathrm{C} 4$ & & II & Periodontite \\
\hline
\end{tabular}

*NT - não tipável 


\subsection{Determinação de características fenotípicas}

\subsubsection{Detecção da produção de cápsula por microscopia óptica}

As colônias de cada amostra de $P$. gingivalis desenvolvidas em ágar Brucella (Oxoid LTDA/256026, Basingstoke, Hampshire, Inglaterra) acrescido de 5\% de sangue desfibrinado de carneiro (Soerensen Laboratórios do Brasil Ltda -Marília, Brasil), $0,5 \mathrm{mg} / \mathrm{ml}$ de hemina e $1 \mathrm{mg} / \mathrm{ml}$ de menadione (Sigma Chemical Co,St Louis, EUA)] após 5 dias de incubação em câmara de anaerobiose (Plas Labs modelo 855-AC/EXPS) em atmosfera $85 \% \mathrm{~N}_{2}, 5 \% \mathrm{CO}_{2}$ e $100 \% \mathrm{H}_{2}$ (Oxilumen, São Paulo, Brasil) foram raspadas com alça estéril e inoculadas em tubos de ensaio contendo $10 \mathrm{ml}$ de meio líquido TSB-HM, composto de caldo Triptone Soja (Oxoid LTDA/256026, Basingstoke, Hampshire, Inglaterra) suplementado com $0,1 \%$ de extrato de levedura (Difco,Le Pont de Claire,França), $0,5 \mathrm{mg} / \mathrm{ml}$ de hemina e 1 $\mathrm{mg} / \mathrm{ml}$ de menadione (Sigma Chemical $C_{0}$ ) até atingir $A_{660}=0,5$, equivalente à fase exponencial de crescimento, em espectrofotômetro (Jenway 645UV/Vis Essex, Inglaterra). Alíquotas de $5 \mu \mathrm{l}$ desta suspensão bacteriana foram misturadas a $5 \mu \mathrm{l}$ de soro eqüídeo (Cripion Biotecnologia LTDA, São Paulo, Brasil), para realização do esfregaço em lâminas de vidro. O esfregaço foi fixado com álcool metílico (Sigma Chemical Co, St. Louis, MO, EUA) seguindo-se coloração negativa pelo método de Hiss (DOETSH, 1981), para evidenciação das cápsulas. O esfregaço foi coberto com solução alcoólica de violeta genciana a $0,75 \%$ durante 1 minuto, seguindo-se lavagem com solução aquosa de sulfato de cobre a uma concentração de 1,25 M. As lâminas foram visualizadas em microscópio óptico e fotografadas. Foi considerada a presença de cápsula quando visualizado um halo sem coloração ao redor do corpo bacteriano na maioria das células do campo. 


\subsubsection{Ensaio de Hidrofobicidade}

A capacidade de adesão ao $n$-hexadecano foi utilizada para determinar a hidrofobicidade relativa da superfície celular das amostras bacterianas, como descrito por Gibbons e Etherden (1983) com algumas modificações. As amostras de referência W83 e ATCC 33277 e clínicas de P.gingivalis foram cultivadas até alcançarem o meio da fase exponencial, como descrito no item 3.2.1.

Ao atingirem a fase estipulada, as culturas foram centrifugadas a 3.000 $\mathrm{xg}$, por 20 minutos, a $4{ }^{\circ} \mathrm{C}$ (Eppendorf-Centrifuge 5402, Hamburg, Alemanha). O precipitado foi lavado três vezes com tampão PUM (16,94 $\mathrm{g} \mathrm{K}_{2} \mathrm{HPO}_{4}, 7,26 \mathrm{~g}$ $\mathrm{KH}_{2} \mathrm{PO}_{4}, 1,8 \mathrm{~g}$ uréia e $0,2 \mathrm{~g} \mathrm{Mg}_{2} \mathrm{SO}_{4} .7 \mathrm{H}_{2} \mathrm{O}$ por litro, $\left.\mathrm{pH} 7,1\right)$ e ressuspenso no mesmo tampão, até atingir a $\mathrm{DO}_{500 \mathrm{~nm}} \sim 0,85$, equivalente a $1 \times 10^{9} \mathrm{UFC} / \mathrm{ml}$. Alíquotas de $3 \mathrm{ml}$ das suspensões bacterianas foram transferidas para tubos de vidro $(10 \times 100 \mathrm{~mm})$ e as $\mathrm{DO}_{550 \mathrm{~nm}}$ foram mensuradas. Alíquotas de $400 \mu \mathrm{l}$ de $\mathrm{n}$ hexadecano (Sigma Chemical Co, St. Louis, MO, EUA) foram adicionadas às suspensões bacterianas, estas foram incubadas em banho a $30^{\circ} \mathrm{C}$ por 10 minutos.

Após a incubação, as suspensões foram homogeneizadas em agitador de tubos por dois períodos de 30 segundos, com um intervalo de 5 segundos de repouso entre cada agitação. Após a separação das fases por manutenção estática (30 minutos), a $\mathrm{DO}_{550 \mathrm{~nm}}$ da fase aquosa foi determinada.

Os experimentos foram realizados em triplicata, em três ensaios independentes, e os valores de hidrofobicidade foram expressos em porcentagem das células aderidas ao n-hexadecano, ou seja, pela porcentagem de bactérias que permaneceram na fase aquosa, após o tratamento com n-hexadecano, em relação ao valor inicial.

As diferenças entre a hidrofobicidade das amostras capsuladas e não capsuladas foi avaliada através do teste de analise estatística, Mann-Whitney. $O$ nível de significância usado foi de $p<0,05$. 


\subsection{Detecção do lócus de síntese de polissacarídeo capsular e do sorotipo K1 por PCR}

\subsubsection{Extração do DNA}

Alíquotas do estoque congelado de cada uma das cepas em $20 \%$ de glicerol em freezer $-80{ }^{\circ} \mathrm{C}$ (Revco) foram inoculadas em placas de ágar sangue suplementado com $0,5 \mathrm{mg} / \mathrm{ml}$ de hemina, $1 \mathrm{mg} / \mathrm{ml}$ de menadione e $5 \%$ de sangue desfibrinado de carneiro (Soerensen Laboratórios do Brasil Ltda). As placas de ágar sangue foram incubadas sob atmosfera de anaerobiose, durante o período de 5 a 10 dias a $37^{\circ} \mathrm{C}$ em câmara de anaerobiose (Plas Lab) em atmosfera de $85 \%$ $\mathrm{N}_{2}, 5 \% \mathrm{CO}_{2}$ e $10 \% \mathrm{H}_{2}$ (Oxilumen).

Após o desenvolvimento das culturas de $P$. gingivalis, as colônias foram transferidas com auxílio de alça estéril plástica padronizadas de $1 \mu$ para tubos de centrifuga de $1,5 \mathrm{ml}$ contendo $300 \mu \mathrm{l}$ de água MiliQ estéril. A extração do DNA foi realizada, através de um Kit de extração de acordo com as instruções do fabricante (Wizard® Genomic DNA Purification Kit - Promega, Madison, WI, EUA).

\subsection{Caracterização do lócus de biossíntese de polissacarídeo capsular (BPC) e detecção do genótipo K1 por PCR}

Os genes pg0106 (que codifica uma glicosiltransferase), pg0111 (gene de biossíntese do polissacarídeo capsular) e pg0118 (que codifica um glicosiltransferase sorotipo específica) foram amplificados por PCR utilizando os pares de iniciadores descritos por Brunner et al. (2008) (Tabela 1).

Os genes pg0106 e pg0111 foram selecionados por ser parte da região mais conservada entre as amostras capsuladas, enquanto as regiões pg0116 a pg0120 são mais heterogêneas (ADUSE e OPOKU et al., 2006).

Para a reação de amplificação foi utilizada Taq DNA Polimerase (Invitrogen, São Paulo, Brasil) de acordo com as instruções do fabricante. A concentração do $\mathrm{MgCl}_{2}$ foi ajustada para $1,5 \mathrm{mM}$, e foram adicionados $5 \mu \mathrm{l}$ de DNA molde, $50 \mathrm{mM}$ de

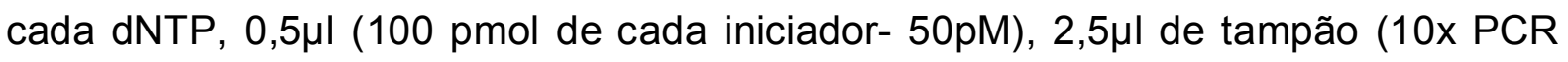
buffer) e 2,5 unidades de Taq DNA polimerase, em um total de reação de $25 \mu$.

As reações de amplificação foram realizadas em termociclador (Gene AmpPCR System 2400, Applied Biosystems, CA, EUA) com desnaturação inicial 
de $95^{\circ} \mathrm{C}$ por $5 \mathrm{~min}$, seguidas por 30 ciclos de $95^{\circ} \mathrm{C}, 55^{\circ} \mathrm{C}$ e $72{ }^{\circ} \mathrm{C}$ por $30 \mathrm{~s}, 30 \mathrm{~s} \mathrm{e}$ $2 \mathrm{~min}$, respectivamente e extensão final a $72{ }^{\circ} \mathrm{C}$ por $5 \mathrm{~min}$. Os produtos da reação foram submetidos à eletroforese em gel de agarose a 1\%, em tampão TAE, corados com brometo de etídio e fotografados no sistema Photo PC $3100 Z$ (EPSON, Hemel Hempstead, Inglaterra). Para evitar a contaminação e falsos resultados positivos, foram utilizadas salas separadas para o estabelecimento da reação de PCR e para a análise dos produtos de PCR. O controle negativo foi constituído da mistura padrão de PCR com o DNA molde trocado por $5 \mu$ l de água estéril. Como controle positivo da reação foi utilizado o DNA da amostra W83 em todas as reações.

Tabela 2 - Iniciadores utilizados para análise do lócus de biossíntese de polissacarídeo capsular

\begin{tabular}{ccc}
\hline \hline Gene & \multicolumn{1}{c}{ Sequencia Nucleotídica } & $\begin{array}{c}\text { Produto } \\
\text { Esperado } \\
\text { (pb) }\end{array}$ \\
\hline$p g 0106$ & $\begin{array}{c}\text { 5' CGGGGATCCATGGGGTATGTTATTGAAG 3' } \\
\text { 5' CGAAGTCGACTCAGACACATCCCCTTTTGC 3' }\end{array}$ & $\begin{array}{c}1.150 \mathrm{pb} \\
\text { pg0111 }\end{array}$ \\
& $\begin{array}{l}\text { 5' GAAGTGGATCCATGCTTAATAATGCCTCCTACCG 3' } \\
\text { 5' CTATAGGAATTCTCATCAGCACACGATTAGCC 3' }\end{array}$ & $1.250 \mathrm{pb}$ \\
pg0118 & 5' TTAAGGAATTCAATGATTATCCCTATGAACAACAAGC 3' & $1.050 \mathrm{pb}$ \\
\hline \hline
\end{tabular}

FONTE: Brunner et al. (2008). 


\subsection{Determinação da estrutura populacional por MLST}

Foi utilizada a metodologia descrita por Koehler et al. (2003) e Enersen et al. (2006) para análise de 26 amostras clínicas e 2 amostras padrões. A extração de DNA destas amostras foi realizada como descrito no item 3.3.1. Foram amplificados sete genes cromossomais que codificam enzimas de manutenção (housekeeping) de $P$. gingivalis originando fragmentos de 380 a 420 pb, utilizando os iniciadores descritos na tabela 3. As reações de amplificação foram realizadas utilizando Taq DNA Polimerase (Invitrogen) de acordo com as instruções do fabricante. A concentração do $\mathrm{MgCl}_{2}$ foi ajustada para $1,5 \mathrm{mM}$, e foram adicionados $5 \mu \mathrm{l}$ de DNA molde, 50mM de cada dNTP, 0,5 $\mu \mathrm{l}$ (100 pmol de cada iniciador50pM), 2,5 $\mu$ l de tampão (10x PCR buffer) e 2,5 unidades de Taq DNA polimerase, em um total de reação de $25 \mu \mathrm{l}$.

As reações de amplificação foram realizadas em termociclador (Gene AmpPCR System 2400, Applied Biosystems) com desnaturação inicial de $94^{\circ} \mathrm{C}$ por 5 min, seguidas por 30 ciclos de $94{ }^{\circ} \mathrm{C}$ por $30 \mathrm{~s}, 55^{\circ} \mathrm{C}$ a $60{ }^{\circ} \mathrm{C}$ como temperatura de anelamento de acordo com o gene e extensão final a $72{ }^{\circ} \mathrm{C}$ por 5 min.

Após a amplificação, os produtos de PCR foram purificados através do kit de purificação QIAquick PCR Purification (Quiagen,Hilden, Alemanha), seguindo as instruções do fabricante. Os produtos de PCR foram enviados ao Centro de Estudos do Genoma Humano, onde foi realizado o seqüenciamento de ambas as fitas de cada gene, utilizando os mesmos pares de iniciadores que utilizados na PCR (tabela 3). As sequências gênicas foram editadas e comparadas com sequências de cada lócus publicadas no endereço eletrônico http://www.pubmlst.org/pgingivalis, através do programa Bionumerics (Applied Maths, Sint Martens Latem, Bélgica) versão 6.0. Com base na combinação dos alelos dos sete lócus, foi atribuído um perfil para cada cepa de acordo com a base de dados. Para avaliar as relações filogenéticas entre os isolados, foi construído um dendrograma com base no perfil dos alelos através do emprego do programa Bionumerics 6.0 (Applied Maths). 
Tabela 3 - Seqüências dos iniciadores utilizados na análise por MLST para amplificação de diferentes genes cromossomais, tamanho do produto, as diferentes temperaturas de anelamento e a função de cada gene.

\begin{tabular}{|c|c|c|c|c|}
\hline Gene & Sequência nucleotídica & $\begin{array}{l}\text { Produto } \\
(\mathrm{pb})\end{array}$ & $\begin{array}{c}\text { Temperatura } \\
\text { de } \\
\text { anelamento } \\
\end{array}$ & Função \\
\hline$g p d x J$ & $\begin{array}{l}\text { 5'GGCAATGTCCCCCGATGTCCTC 3' } \\
\text { 5'GATACCCGAGACCGAGCGAATG 3' }\end{array}$ & $501 \mathrm{pb}$ & $61^{\circ} \mathrm{C}$ & $\begin{array}{l}\text { Sintetase fosfato de } \\
\text { pirodoxal }\end{array}$ \\
\hline pga & $\begin{array}{l}\text { 5'GATCTGGCCCTGCCAACCACAC 3' } \\
\text { 5'TTGCCCGATCCTCCTCCATAAA 3' }\end{array}$ & $693 \mathrm{pb}$ & $60^{\circ} \mathrm{C}$ & Transposase \\
\hline hagB & $\begin{array}{l}\text { 5'CGTCGTGCAGCGGCTCCAAAAT 3' } \\
\text { 5' CGGCGCACCACGGCTACC 3' }\end{array}$ & $560 \mathrm{pb}$ & $60^{\circ} \mathrm{C}$ & Hemaglutinina \\
\hline$m c m A$ & $\begin{array}{l}\text { 5'ACAAGGCGTGGACACTCATCAAG 3' } \\
\text { 5' TGCCCGTCCTGCCCCATTTT 3' }\end{array}$ & $562 \mathrm{pb}$ & $59^{\circ} \mathrm{C}$ & $\begin{array}{l}\text { Metilmalonil } \\
\text { coenzima A }\end{array}$ \\
\hline recA & $\begin{array}{l}\text { 5'TGGCCACGGAGAAGATAGAGA 3' } \\
\text { 5'GGATGTCGATGCGGATGGA 3' }\end{array}$ & $642 \mathrm{pb}$ & $57^{\circ} \mathrm{C}$ & Reparação do DNA \\
\hline$f t s Q$ & $\begin{array}{l}\text { 5'TTGCAGCCAATAGTTTTCTTTTC 3' } \\
\text { 5'TTTTTCTGCCCAATTAGGTGTA 3' }\end{array}$ & $566 \mathrm{pb}$ & $56^{\circ} \mathrm{C}$ & Divisão celular \\
\hline pepO & $\begin{array}{l}\text { 5'AGCTGCTTACCATACCTACG 3' } \\
\text { 5'AGCTGCTTACCATACCTACG 3' }\end{array}$ & $642 \mathrm{pb}$ & $55^{\circ} \mathrm{C}$ & Endotelina \\
\hline
\end{tabular}




\section{RESULTADOS}

\subsection{Detecção da produção de cápsula por microscopia óptica}

Foram analisadas as cepas de $P$. gingivalis de referência ATCC 33277 , não-capsulada, e W83, produtora de cápsula, e 26 isolados clínicos.

A figura 2 mostra a imagem de P.gingivalis W83 cuja cápsula foi corada negativamente pela coloração de Hiss. A cápsula de P.gingivalis apresenta natureza polissacarídica, não retendo a violeta genciana e, portanto é removida pelo sulfato de cobre (Figura 2). A presença de cápsula foi observada em 16 das 28 amostras analisadas (57\%) (Figura 3), inclusive na amostra W83 (controle positivo), mas não na amostra ATCC 33277 (controle negativo).
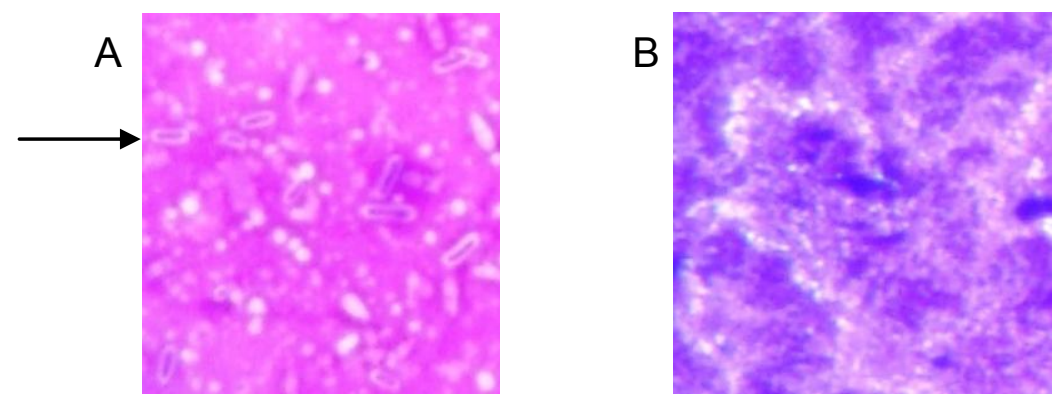

Figura 2 - Microfotografia de células de $P$. gingivalis após coloração de Hiss. (A) W83: A seta aponta a célula bacteriana corada e cápsula com coloração negativa. (B) ATCC33277, ausência de cápsula.

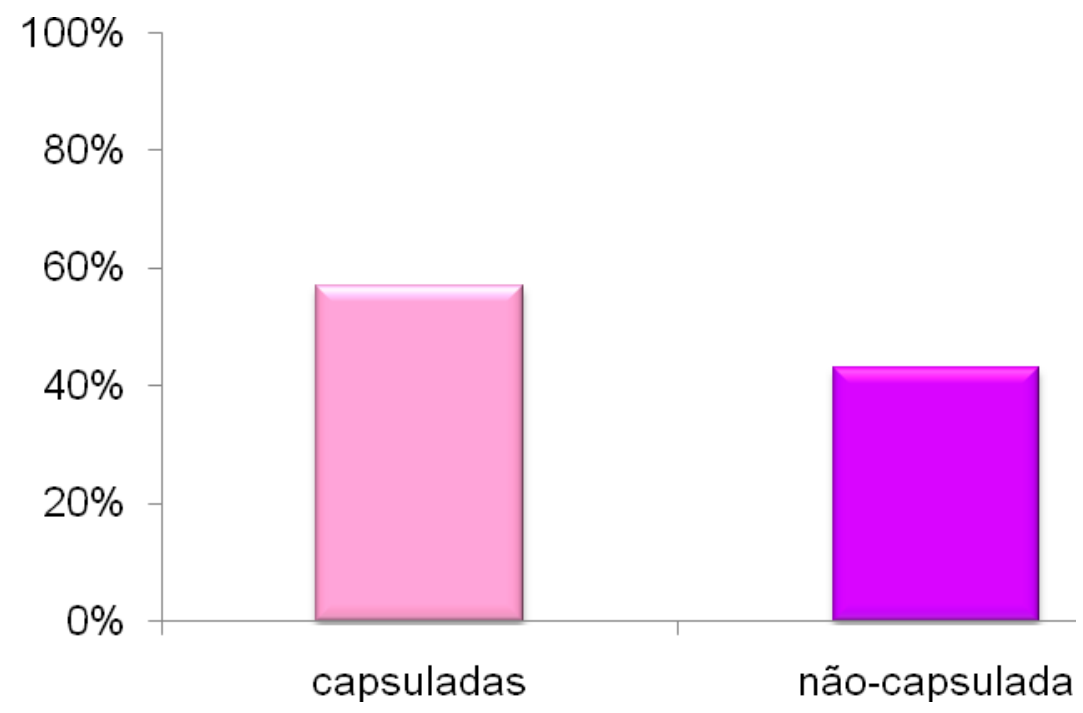

Figura 3 - Análise da prevalência de cepas capsuladas e não capsuladas de P.gingivalis através de porcentagem. 


\subsection{Ensaio de hidrofobicidade}

Os valores da hidrofobicidade das amostras capsuladas e não-capsuladas foram expressos como porcentagem de células bacterianas aderidas ao nhexadecano. A tabela 4 apresenta os valores de hidrofobicidade de amostras capsuladas e não-capsuladas de P.gingivalis. A amostra de referência nãocapsulada ATCC33277 mostrou-se mais hidrofóbica (\% média de células aderidas ao hexadecano $=18 \pm 4,3)$ do que a amostra padrão capsulada W83 $(6 \pm 1,3)$. No entanto, este comportamento não foi homogêneo entre amostras em relação a presença da cápsula, não sendo detectadas diferenças significantes nos valores de hidrofobicidade de amostras capsuladas e não-capsuladas de isolados clínicos de P.gingivali (Figura 4) (Teste Mann-Whitney, $\mathrm{p}=0,66$ ). 
Tabela 4 - Valores de média, mediana e desvio padrão da porcentagem de células que permaneceram aderidas ao n-hexadecano em relação ao valor inicial (hidrofobicidade) de amostras de $P$.gingivalis capsuladas e não-capsuladas.

\begin{tabular}{lccc}
\hline \multicolumn{1}{c}{ Amostra } & Média & Mediana & Desvio Padrão \\
\hline Capsuladas & 7,4 & 6 & 6,4 \\
Não-capsuladas & 6,7 & 4,1 & 6,9 \\
& & & \\
\hline \hline
\end{tabular}

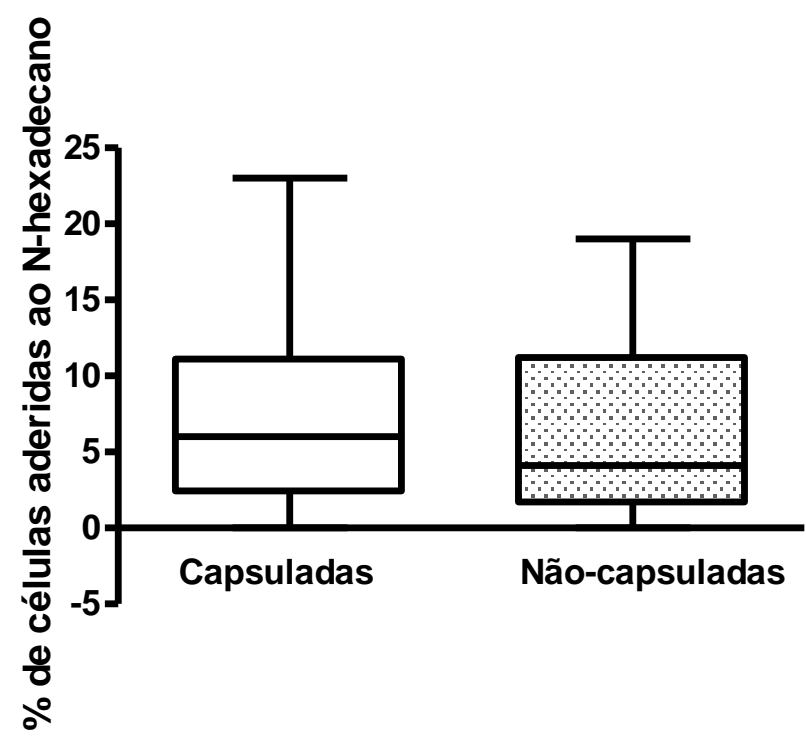

Figura 4 - Gráfico representando os valores de mediana, quartil superior e inferior, e desvio padrão da porcentagem de células aderidas ao n-hexadecano (hidrofobicidade) em amostras capsuladas e não capsuladas de P.gingivalis. Teste estatístico de Mann-Whitney - diferenças não significantes ( $P>0,05)$. 
4.3 Detecção do lócus de síntese de polissacarídeo capsular e do sorotipo K1 por PCR

\subsubsection{Detecção do gene pg0106}

Quando utilizado como molde em PCR, DNA de 22 entre 28 amostras testadas foi obtido amplicom para o gene pg0106, que codifica uma glicosiltransferase. As reações com as amostras de referência resultaram em produtos com tamanho esperado, como ilustrado na figura 5. É possível observar na figura 6, que o gene pg0106 está presente tanto em amostras capsuladas como em amostras que não apresentam cápsula, sendo detectado em $75 \%$ das amostras capsuladas e em $83 \%$ das amostras não capsuladas.

O gene pg0106 não foi detectado nas seguintes amostras que apresentaram cápsula: P986, 268A2, 381A, 259C3; e em duas amostras que não apresentaram esta estrutura :381C e alfa. 


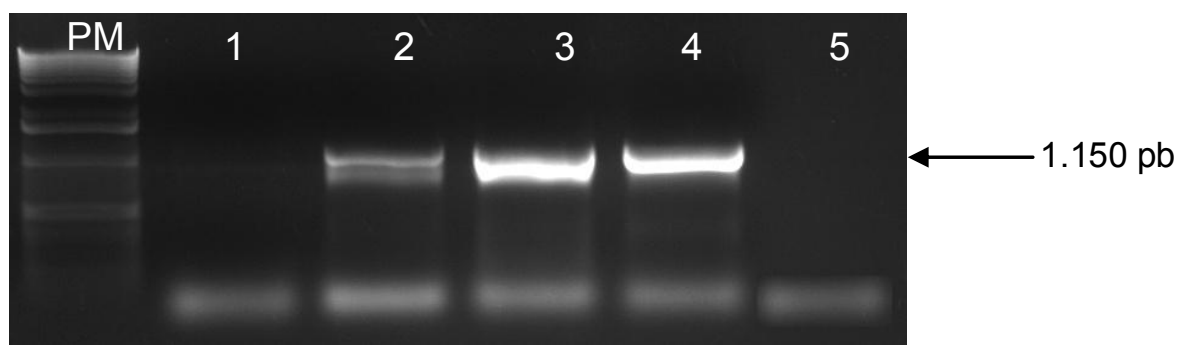

Figura 5 - Fotografia de gel de agarose 1\% corado com brometo de etídio onde os amplicons da reação de PCR para detecção do gene pg106 foram submetidos a corrida eletroforética em tampão TAE. PM: marcador de peso molecular $1 \mathrm{~Kb}$. Produto de amplificação utilizando como molde DNA das amostras clínicas. Em 1. Alfa, em 2: 6 26, em 3: ATCC 33277, em 4: W83, em 5: controle negativo. Observa-se produto de cerca de $1.150 \mathrm{pb}$ resultado da amplificação do gene pg0106 apenas nas canaletas 2, 3 e 4.

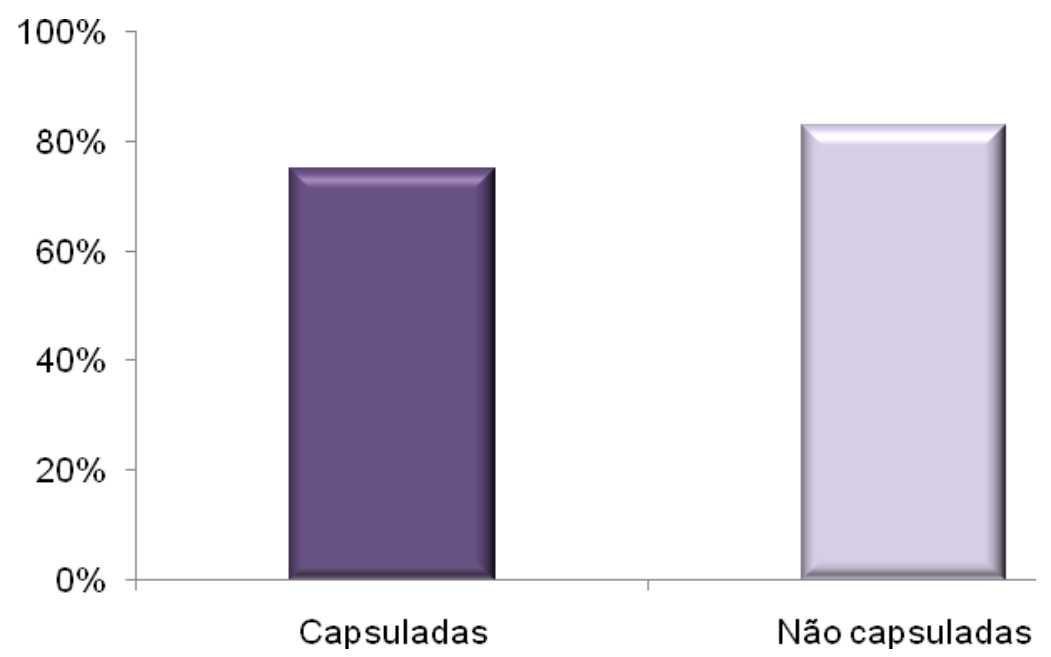

Figura 6 - Distribuição das cepas de P.gingivalis de acordo com a presença de cápsula e detecção do gene pg0106 por PCR. 


\subsubsection{Detecção do gene pg0111}

Usando iniciadores complementares à sequência da amostra W83, o gene pg0111, que codifica uma glicosiltransferase do lócus de biossíntese do polissacarídeo capsular, foi detectado em 5 de 28 amostras analisadas, sendo que todas as amostras positivas para este gene eram capsuladas. No entanto, o DNA de 11 entre 16 amostras capsuladas não resultou em amplicom, indicando que deve ocorrer variação na sequência da região dos iniciadores empregados para este gene, mesmo entre as amostras capsuladas. A fotografia do gel representativo da detecção de pg0111 pode ser observada na figura 7 . Na figura 8 encontra-se a representação gráfica da distribuição de amostras em relação à detecção do gene pg0111 e a presença de cápsula, mostrando que uma pequena parte das amostras capsuladas apresentaram este gene (31\%). 


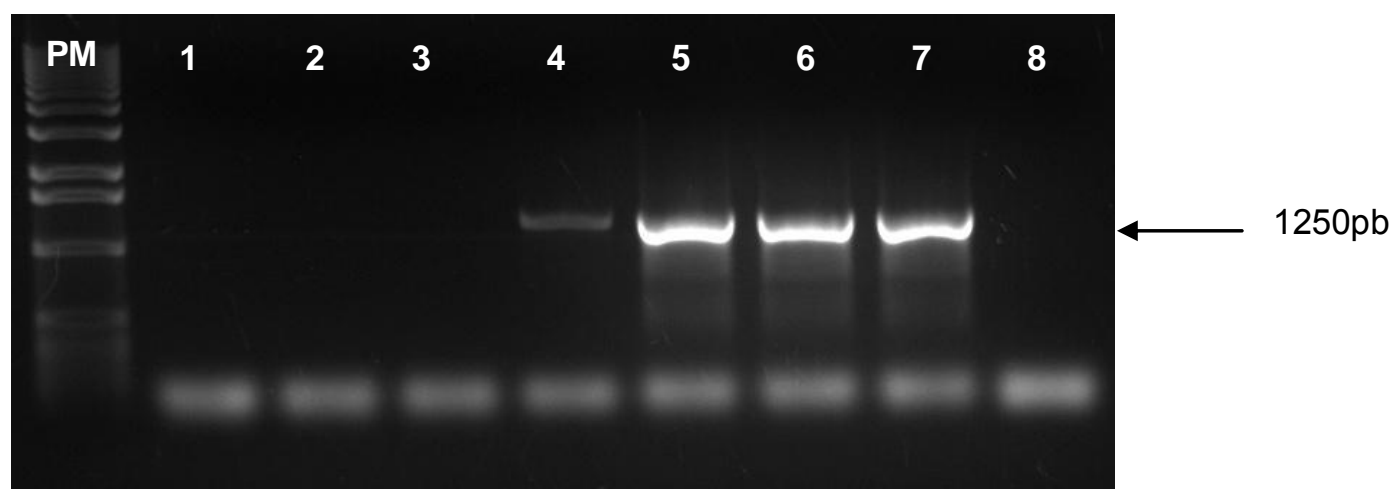

Figura 7 - Fotografia de gel de agarose 1\% corado com brometo de etídio onde os amplicons obtidos na reação de PCR para o gene pg0111 foram submetidos a corrida eletroforética em tampão TAE. PM: marcador de peso molecular $1 \mathrm{~Kb}$. Produto de amplificação utilizando como molde DNA das amostras clínicas em: 1. 279C1, em 2. 275C4, em 3: ATCC 33277, em 4: 9C, em 5:324A4, em 6: P9/86, 7: controle positivo (W83), 8: controle negativo. Observa-se produto de amplificação de 1250 pb resultado da amplificação do gene pg111 nas canaletas 4,5,6 e 7 (controle positivo).

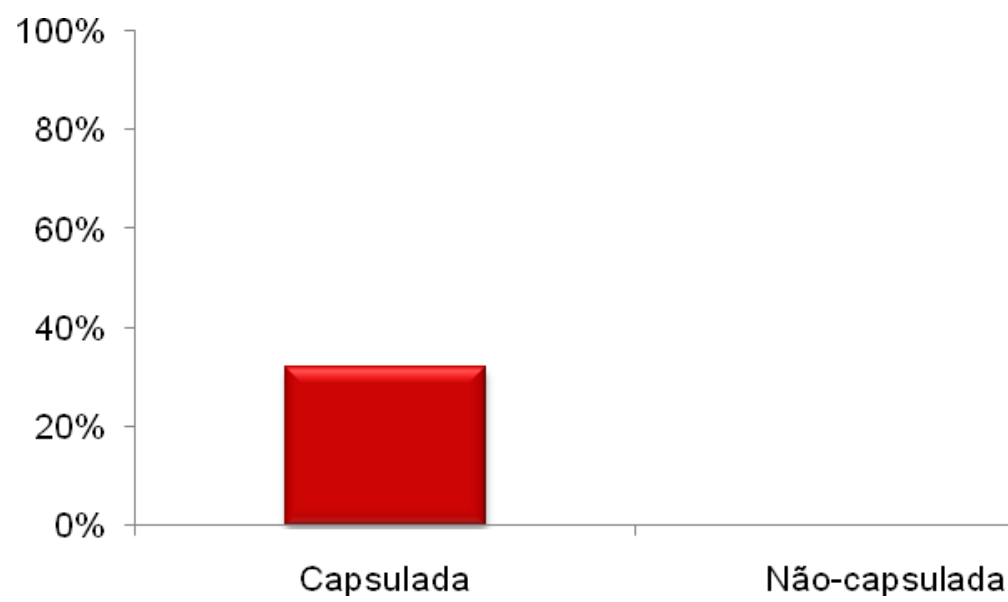

Figura 8 - Distribuição de cepas de P.gingivalis em que o gene pg0111 foi detectado por PCR, de acordo com a presença de cápsula. 


\subsubsection{Detecção do gene pg0118}

O gene pg0118 presente no lócus da biossíntese do polissacarídeo capsular é K1 especifico. Assim, este gene não foi detectado nos isolados clínicos não capsulados e na amostra ATCC33277 (Figuras 9 e 10). No entanto, este gene foi detectado em apenas um dos isolados clínicos capsulados entre os 16 testados (amostra 9C), além de na amostra padrão W83 (controle positivo).

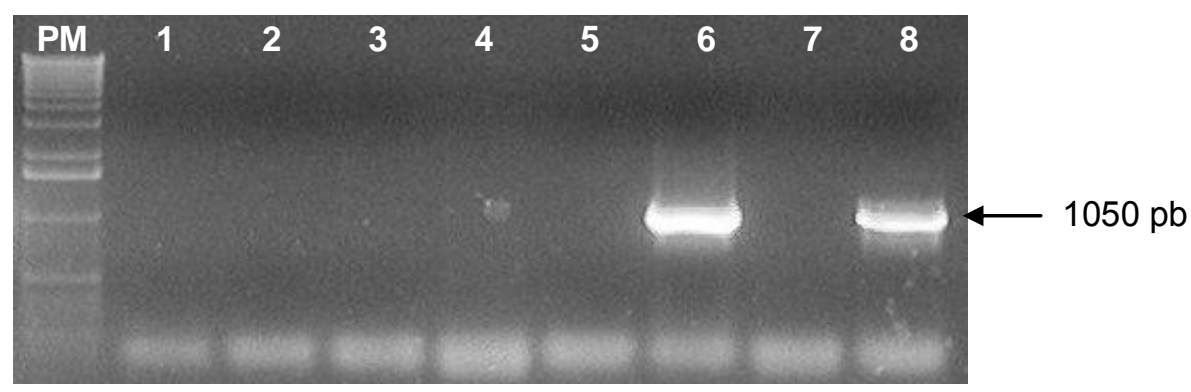

Figura 9 - Fotografia de gel de agarose 1\% corado com brometo de etídio onde os amplicons da reação de PCR para o gene pg0118 foram submetidos a corrida eletroforética em tampão TAE. PM: marcador de peso molecular $1 \mathrm{~Kb}$. Produto de amplificação utilizando como molde DNA das amostras clínicas em: 1. 279C1, em 2. 381B, em 3: beta, em 4: HW, em 5: 259C3, em 6: 9C, 7: controle negativo, 8: controle positivo (W83). Observa-se produto de amplificação de $1.050 \mathrm{pb}$ resultado da amplificação do gene pg118 apenas nas canaletas 6 e 8 (controle positivo).

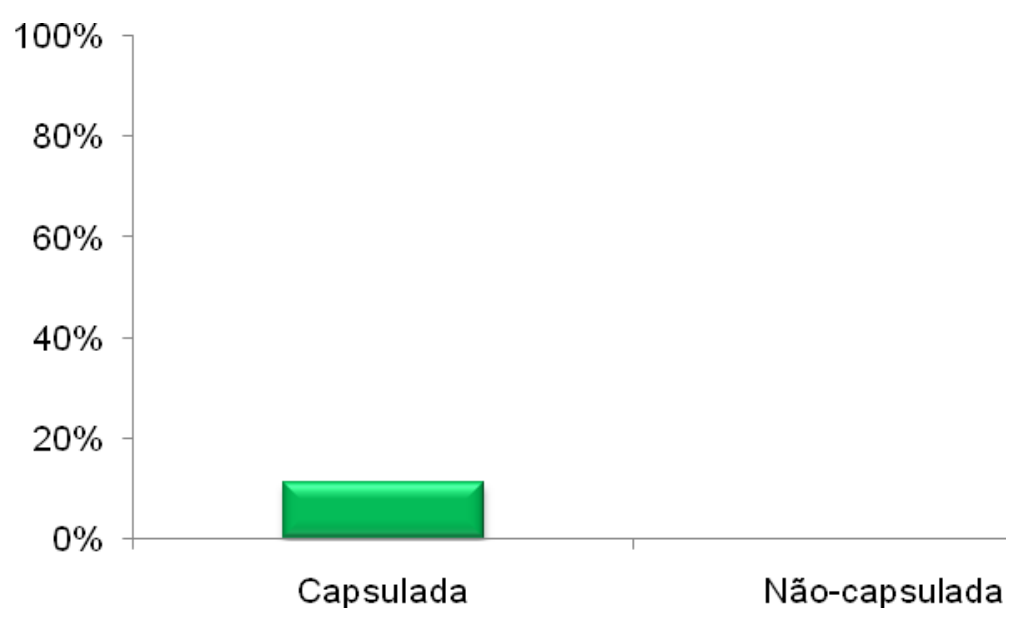

Figura 10 - Distribuição de cepas de $P$. gingivalis em que o gene pg0118 foi detectado por PCR, de acordo com a presença de cápsula. 


\subsection{Determinação da estrutura populacional por MLST}

Foram realizadas as amplificações dos sete genes de manutenção (housekeeping) citados na tabela 4, sendo que foram obtidas sequências em todas as amostras, com exceção de duas amostras (259C3 e alfa). Estas amostras foram identificadas como $P$. gingivalis utilizando iniciadores espécie-específicos, complementares à região $16 \operatorname{SrRNA}$ de $P$. gingivalis e suas características encontram-se abaixo do dendrograma. Assim, as seqüências obtidas a partir de DNA de 26 amostras foram aqui analisadas (Figura 11).

Foi possível determinar as STs de 8 amostras, com base nos dados publicados previamente, entre elas as amostras de referência ATCC 33277 e W83 (KOEHLER et al., 2003; ENERSEN et al., 2008). Portanto, 18 amostras foram classificadas em novos STs. Foram também observados 17 novos alelos, diferindo dos já depositados no banco de dados, sendo que essas sequências foram encaminhadas para análise e inclusão no banco de dados, para publicação no endereço eletrônico http://www.pubmlst.org/pgingivalis (Tabela 5). A análise do número de diferentes e novos alelos encontrados neste estudo, mostrou que o gene $f t s Q$ apresentou o maior número de alelos diferentes, sendo um dos genes que apresentou o maior número de alelos novos juntamente com os genes gdpxJ, hagB e $p g A$, enquanto que o gene recA apresentou menor número de alelos diferentes, e o gene pepO apresentou menor número de alelos novos (Tabela 6). Estes dados indicam que apesar das analises do MLST serem feitas com genes de manutenção, é possível que ocorra variabilidade entre estes genes.

A análise filogenética mostrou grande diversidade de $P$. gingivalis, como apresentado no dendrograma (Figura 11). As amostras de $P$. gingivalis analisadas foram classificadas em 3 grandes grupos com similaridade maior que 30\% (Tabela 7). O grupo I é formado por três subgrupos A, B e C, enquanto o grupo II é formado por dois subgrupos $\mathrm{D}$ e $\mathrm{E}$, e o grupo III por um subgrupo, com similaridade dentro de cada subgrupo $>50 \%$. Para cada amostra foram anotados o genótipo fimA, presença de cápsula e dos genes da cápsula. Além disso, comparando os diferentes grupos e subgrupos quanto à porcentagem de hidrofobicidade, observase tendência em capacidade hidrofóbica similar e a distribuição no dendrograma. Por exemplo, o ST formado pelas amostras $279 \mathrm{C} 1$ e 261A1, apresenta hidrofobicidade similar $(15,5 \%$ e $16,9 \%$, respectivamente). O mesmo pode ser 
observado para os ST formados pelas amostras 381A e 381C (1,9\% e 1,6 \%), $275 \mathrm{C} 4$ e HW ( $0 \%$ e 0,6\%), 9C e W83 (10\% e 6\%), mas não para o grupo C, formado pelas amostras ATCC33277, beta e gama $(18 \%, 0 \%$ e $0 \%$, respectivamente). Além disso, as amostras classificadas no grupo III apresentam valores semelhantes quanto à hidrofobicidade, e menor porcentagem de hidrofobicidade (Tabela 7). Ao contrário do esperado, a hidrofobicidade não se relacionou a ausência de cápsula, mesmo comparando-se amostras bastante similares pela análise filogenética, como as amostras 275C4 e HW, capsulada e não capsuladas, respectivamente.

Assim, apesar de algumas amostras apresentarem 100\% de similaridade pela análise filogenética, estas podem exibir diferenças quanto ao genótipo fimA e a presença de cápsula. Por exemplo, dois isolados clínicos (Beta e gama) e amostra ATCC 33277 mostraram 100\% de similaridade, porém a amostra Beta apresentou cápsula e foi classificada como genótipo $\operatorname{fim} A \mathrm{lb}$, enquanto as demais não apresentam cápsula e pertencem ao genótipo fimA I. Por outro lado, a hidrofobicidade de ATCC 33277 foi muito maior que a observada na demais amostras do mesmo ST. Assim como as amostras 268 A1 e 268 A2 que são isolados clínicos do mesmo paciente e apresentam $100 \%$ de similaridade, porém 268 A1 apresentam cápsula e apresenta o gene pg0106 diferindo da amostra 268 A2.

Estes resultados confirmam que o lócus de biossíntese de polissacarídeo capsular é disperso entre as linhagens, e que as amostras de um mesmo genótipo fimA apresentaram heterogeneidade. Mas é interessante notar que seis das sete amostras analisadas pertencentes ao genótipo fimA II estão classificadas no grupo filogenético II, e a restante no grupo III. Ainda, 5 das 8 amostras classificadas nos genótipos I e lb foram classificadas no grupo filogenético I, e duas das restantes também pertencem ao grupo filogenético III. Além disso, vale ressaltar que, as quatro amostras analisadas do genótipo fimA IV apresentaram cápsula, e estas foram distribuídas tanto no grupo filogenético I como no grupo II. Não foi observada relação entre a origem da amostra e o grupo filogenético, sendo os grupos I e II formados por amostras de várias origens. Foram também observados STs comuns entre amostras obtidas de diferentes localizações geográficas como 9C e W83, isoladas no Brasil e EUA, respectivamente, ou 275C4 e HW24D-1, isoladas no Brasil e Japão, respectivamente. No entanto, as três amostras classificadas no 
grupo filogenético III, que apresenta menor similaridade com os demais grupos filogenéticos, foram obtidas no Brasil.

Tabela 5 - Número dos alelos para cada gene analisado e sequence types (STs) de cada uma das amostras analisadas através de MLST.

\begin{tabular}{|c|c|c|c|c|c|c|c|c|}
\hline Amostra & $\overline{~ f t s Q}$ & $\overline{\text { gdpxJ }}$ & hagB & $\overline{\mathrm{mcmA}}$ & pepO & $\overline{\text { pgA }}$ & recA & № da ST \\
\hline $6-26$ & * & * & 1 & 23 & 17 & 21 & 5 & $\star \star *$ \\
\hline Kd865 & 19 & 8 & 1 & 17 & 6 & 12 & 1 & $* *$ \\
\hline 261A1 & * & 22 & * & * & 8 & 2 & 1 & $* *$ \\
\hline $279 C 1$ & 11 & * & 1 & 15 & 6 & 5 & * & ** \\
\hline $316 A B$ & 14 & 22 & 1 & 17 & 8 & 7 & 2 & 73 \\
\hline $9 \mathrm{C}$ & 16 & 6 & 1 & 4 & 1 & 3 & 5 & 24 \\
\hline W83 & 16 & 6 & 1 & 4 & 1 & 3 & 5 & 24 \\
\hline $241 C D$ & 25 & 13 & 1 & 5 & 2 & 3 & * & ** \\
\hline ATCC 33277 & 5 & 9 & 1 & 1 & 1 & 5 & 5 & 96 \\
\hline Beta & 5 & 9 & 1 & 1 & 1 & 5 & 5 & 96 \\
\hline Gama & 5 & 9 & 1 & 1 & 1 & 5 & 5 & 96 \\
\hline 268A1 & 17 & 14 & 20 & 15 & 6 & * & 1 & ** \\
\hline $268 \mathrm{~A} 2$ & 17 & 14 & 20 & 15 & 6 & * & 1 & $* *$ \\
\hline HNA & 17 & 34 & 34 & 29 & 6 & 25 & 1 & 99 \\
\hline $381 \mathrm{~A}$ & 3 & 5 & 17 & 9 & 6 & 4 & 2 & $* *$ \\
\hline $381 C$ & 3 & 5 & 17 & 9 & 6 & 4 & 2 & $* *$ \\
\hline $275 \mathrm{C} 4$ & 10 & * & * & 3 & 6 & 4 & 2 & $* *$ \\
\hline HW24D-1 & 10 & 5 & 13 & 3 & 6 & 4 & 2 & $* *$ \\
\hline HG564 & 17 & 5 & 20 & 3 & 6 & 3 & 1 & $* *$ \\
\hline $\mathrm{Kd} 289$ & 14 & 7 & 37 & 3 & 8 & 7 & 2 & $* *$ \\
\hline $251 \mathrm{C} 2$ & 16 & 3 & 12 & * & 16 & 3 & 1 & $* *$ \\
\hline P1604 & 36 & 5 & 20 & 3 & * & 12 & 1 & $* *$ \\
\hline P9/86 & 12 & 9 & * & 3 & 16 & 3 & 3 & $* *$ \\
\hline 259B1 & 3 & 6 & 6 & 3 & 12 & * & 3 & ** \\
\hline $324 \mathrm{~A} 4$ & * & 6 & 3 & 3 & 8 & 7 & 2 & $* *$ \\
\hline 322B1 & 4 & 32 & 1 & 1 & 23 & 20 & 3 & 67 \\
\hline
\end{tabular}

Novos alelos descritos neste estudo $\left(^{*}\right)$

Novos STs descritos neste estudo $\left({ }^{* *}\right)$. 
Tabela 6 - Número de alelos previamente identificados no banco de dados, número de alelos primeiramente detectados neste estudo (alelos novos) e número total de alelos para cada gene determinados por MLST em amostras de $P$. gingivalis.

\begin{tabular}{cccc}
\hline \hline Genes & $\begin{array}{c}\text { No de alelos identificados } \\
\text { no banco de dados }\end{array}$ & $\begin{array}{c}\text { № de alelos } \\
\text { novos }\end{array}$ & $\begin{array}{c}\text { Número total } \\
\text { de alelos }\end{array}$ \\
\hline$f t s Q$ & 12 & 3 & 15 \\
$g d p x J$ & 11 & 3 & 14 \\
$h a g B$ & 9 & 3 & 12 \\
$m c m A$ & 9 & 2 & 11 \\
$p e p O$ & 8 & 1 & 9 \\
$p g A$ & 9 & 3 & 12 \\
$r e c A$ & 4 & 2 & 6 \\
\hline \hline
\end{tabular}


Sts fimA Cápsula pg0106 pg0111 pg0118 Hidrofobicidade

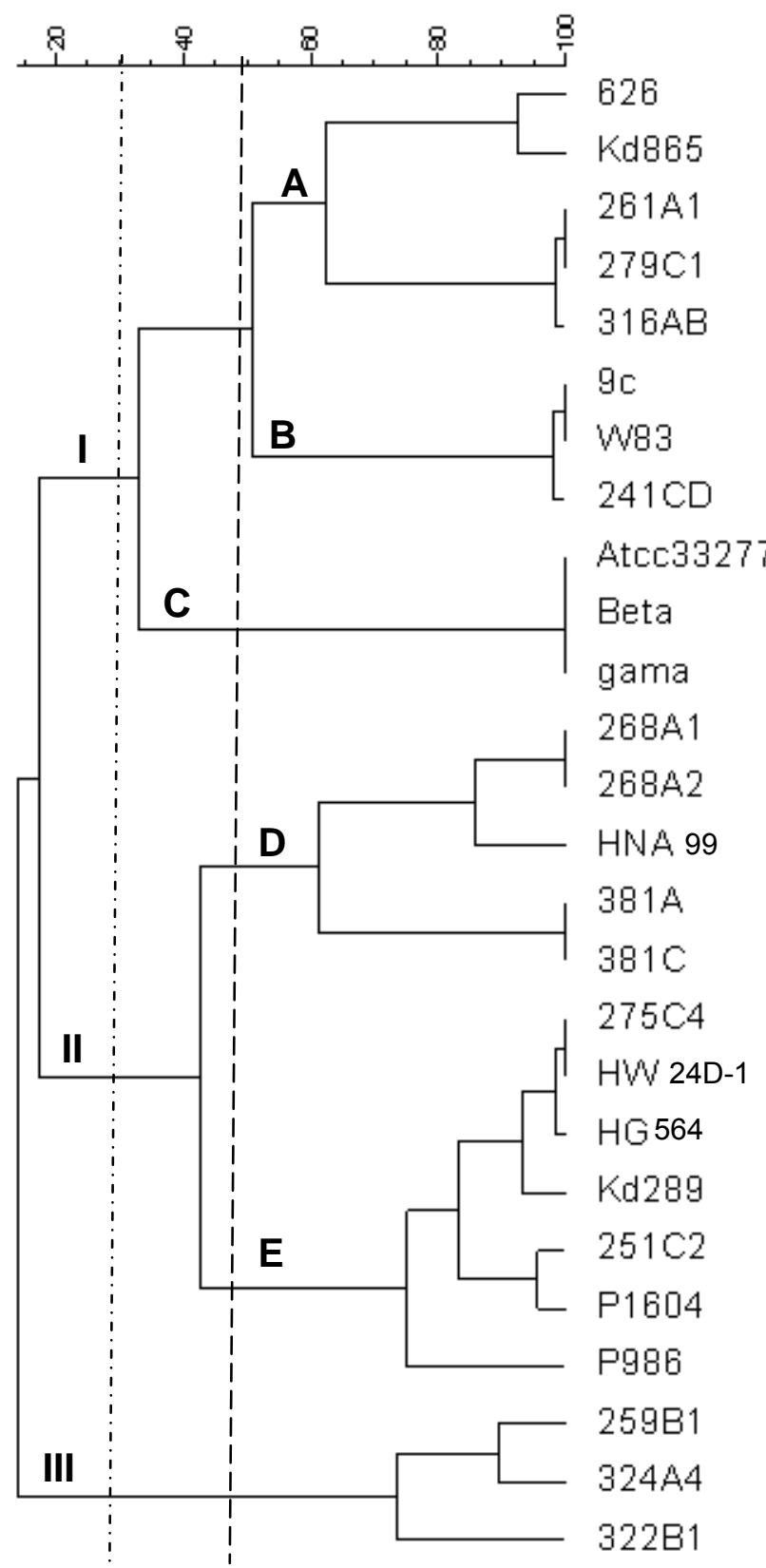

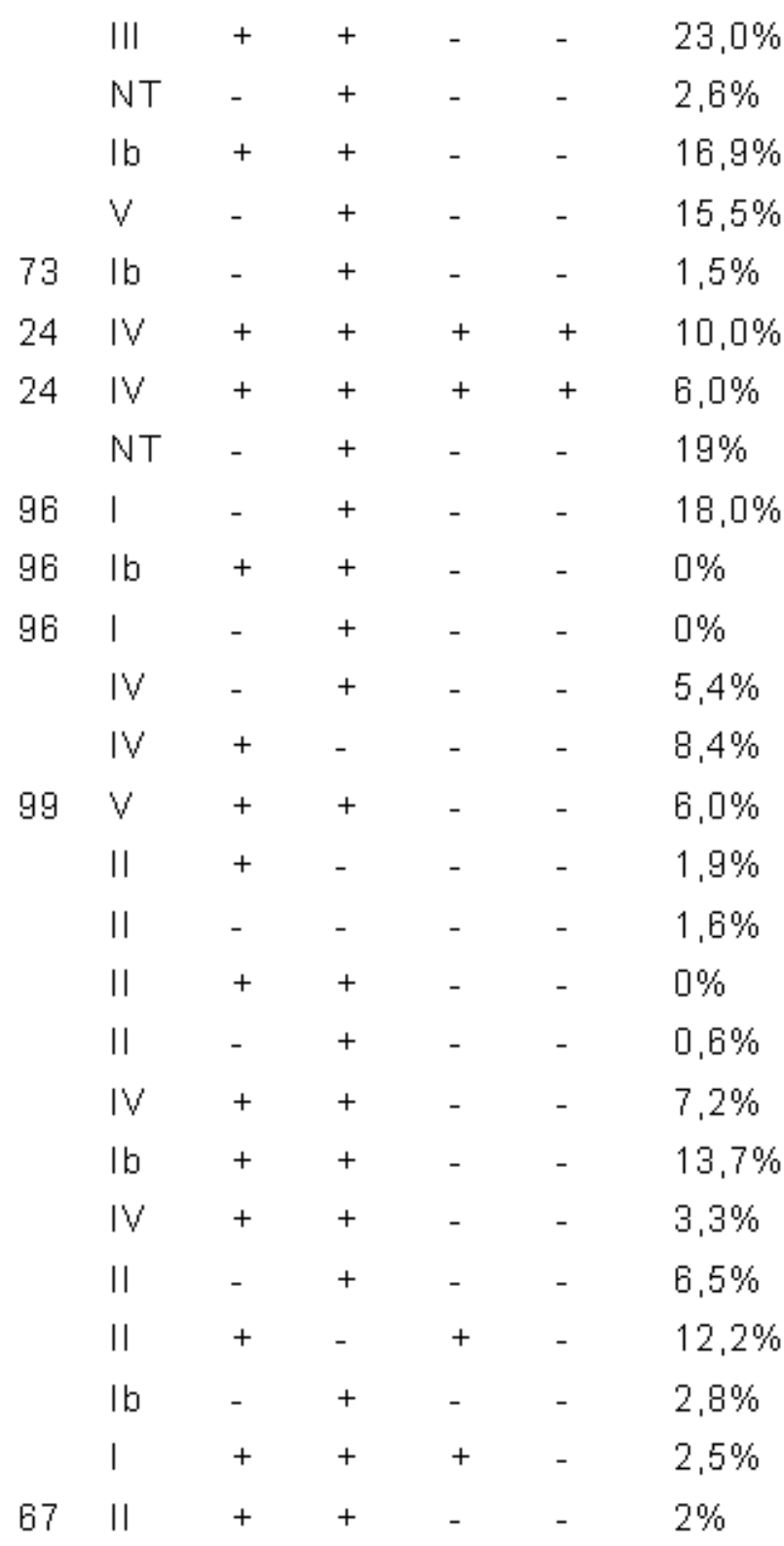

Amostras não tipáveis por MLST

$\begin{array}{lrlllll}259 \mathrm{C} 3 & \mathrm{Ib} & + & - & + & - & 4,9 \% \\ \text { Alfa } & \text { NT } & - & - & - & - & 6,9 \%\end{array}$

Figura 11 - Dendrograma baseado no coeficiente de similaridade DICE construído através do algorítimo UPGMA, mostrando o padrão de similaridade de 25 cepas de $P$. gingivalis e a baixo do dendrograma encontra-se as amostras não tipáveis aos genes de manutenção (housekeeping). A barra superior indica a porcentagem de similaridade entre cepas. Os dados foram comparados ao genótipo fimA, a presença de cápsula, à detecção de genes do lócus de biossíntese de polissacarídeo capsular e a hidrofobicidade. NT: não tipável. ST: sequence type. 
Tabela 7 - Número de amostras de P.gingivalis classificadas quanto ao genótipo fimA, produção da cápsula, genes do polissacarídeo capsular e hidrofobicidade distribuídas em diferentes grupos filogenéticos determinados por MLST.

\begin{tabular}{|c|c|c|c|c|c|c|c|c|}
\hline & \multicolumn{8}{|c|}{ Grupos MLST } \\
\hline & \multicolumn{3}{|c|}{ 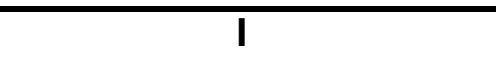 } & \multicolumn{4}{|c|}{ II } & \multirow{2}{*}{$\begin{array}{c}\text { III } \\
(n=3)\end{array}$} \\
\hline & $A(n=5)$ & $B(n=3)$ & $\mathbf{C}(\mathrm{n}=3)$ & $\begin{array}{c}\text { Total } \\
\text { Grupo I }\end{array}$ & $\mathbf{D}(\mathrm{n}=4)$ & $E(n=7)$ & $\begin{array}{c}\text { Total } \\
\text { Grupo } \\
\text { II }\end{array}$ & \\
\hline Genótipo fimA & $\begin{array}{l}\text { III (1) } \\
\mathrm{NT}^{*}(1) \\
\mathrm{Ib}(2) \\
\mathrm{V}(1)\end{array}$ & $\begin{array}{l}\text { IV (2) } \\
\mathrm{NT}^{*}(1)\end{array}$ & $\begin{array}{l}\mathrm{I}(2) \\
\mathrm{lb}(1)\end{array}$ & $\begin{array}{c}\text { I (2) } \\
\text { Ib (3) } \\
\text { III (1) } \\
\text { IV (2) } \\
\text { V (1) } \\
\mathrm{NT}^{*}(2)\end{array}$ & $\begin{array}{l}\text { IV (2) } \\
\text { V (1) } \\
\text { II (2) }\end{array}$ & $\begin{array}{l}\text { II (4) } \\
\text { IV (2) } \\
\text { Ib (1) }\end{array}$ & $\begin{array}{l}\text { Ib (1) } \\
\text { II (4) } \\
\text { IV (4) } \\
\text { V (1) }\end{array}$ & $\begin{array}{l}\text { Ib } \\
\text { I } \\
\text { II }\end{array}$ \\
\hline $\begin{array}{l}\text { Presença de } \\
\text { cápsula }\end{array}$ & 2 & 2 & 1 & & 3 & 5 & & 2 \\
\hline $\begin{array}{l}\text { Detecção de } \\
\text { pg106 }\end{array}$ & 5 & 3 & 3 & & 1 & 6 & & 3 \\
\hline $\begin{array}{c}\text { Detecção de } \\
\text { pg0111 }\end{array}$ & 0 & 2 & 0 & & 0 & 1 & & 1 \\
\hline $\begin{array}{l}\text { Detecção de } \\
\text { pg0118(K1) }\end{array}$ & 0 & 2 & 0 & & 0 & 0 & & 0 \\
\hline $\begin{array}{l}\text { Média } \pm \text { desvio } \\
\text { padrão de } \\
\text { Hidrofobicidade }\end{array}$ & $\begin{array}{c}11,9 \pm \\
9,4\end{array}$ & $\begin{array}{c}11,6 \pm \\
6,7\end{array}$ & $\begin{array}{c}6 \pm \\
10,4\end{array}$ & $\begin{array}{c}9,9 \pm \\
3,3\end{array}$ & $\begin{array}{c}4,7 \pm \\
2,9\end{array}$ & $\begin{array}{r}6,2 \pm \\
5,3\end{array}$ & $\begin{array}{c}5,4 \pm \\
1,1\end{array}$ & $\begin{array}{c}2,4 \pm \\
0,4\end{array}$ \\
\hline
\end{tabular}

NT*: Não tipável 


\section{DISCUSSÃO}

Em bactérias, é comum a observação de perfis de virulência distintos entre organismos da mesma espécie, denominados patovars (SCHMIDT, 2010). Em alguns patógenos, a aquisição de ilhas de patogenicidade por transferência horizontal resultou em diferentes patovars (PORWOLLIK et al., 2002; SCHMIDT, 2010), em outros, os patovars resultaram da aquisição de outros elementos genéticos móveis como prófagos (KUNG; OZER; HAUSER, 2010; SCHMIDT, 2010). Este arsenal de virulência é usado para alterar as funções celulares do hospedeiro, permitindo maior adaptação, virulência e patogenicidade.

O principal lócus de biossíntese de cápsula encontrado no cromossomo de amostras de $P$. gingivalis apresenta características de ter sido transferido horizontalmente (CHEN et al., 2004). Assim, de acordo com a disseminação deste lócus entre as linhagens desta espécie, seria possível que amostras capsuladas e não capsuladas fossem a expressão de patovars distintos, e que cada patovar compartilhasse outras características fenotípicas similares, não somente por apresentarem genes acessórios comuns, mas também por serem originados de um mesmo ancestral. Em estudo recente visando determinar o genoma essencial (core genome) de P. gingivalis, 12 de 14 genes do lócus BPC analisados por microarranjo foram considerados aberrantes, embora apenas uma amostra não capsulada tenha sido analisada (BRUNNER et al., 2010b).

Assim, no presente estudo, nos propusemos a determinar a estrutura filogenética de uma população de $P$. gingivalis composta por amostras capsuladas e não capsuladas.

P.gingivalis é considerado o principal organismo associado à periodontite crônica e a expressão de certos fatores de virulência foi associada à sua sobrevivência no hospedeiro (HOLT et al., 1988; DARVEAU et al., 1997; PATHIRANA et al., 2010). Uma das principais características de organismos residentes na cavidade oral é a capacidade de aderir a uma variedade de superfícies, visto que este aspecto é crítico para sua manutenção no ambiente oral.

As fímbrias e a cápsula de $P$. gingivalis participam da interação da bactéria com a célula epitelial (SOJAR et al., 2002) e a outras bactérias orais como Treponema denticola (HASHIMOTO et al., 2003), Streptococcus oralis (MAEDA et al., 2004) e F. nucleatum (ROSEN e SELA, 2006; METZGER et al., 2009). Por 
outro lado, a cápsula cria uma barreira protetora possibilitando maior sobrevivência da bactéria nos tecidos do hospedeiro (ALBERTI-SEGUI et al., 2010).

Estudos têm relatado maior virulência conferida às cepas capsuladas de $P$. gingivalis pela sua capacidade de indução de abscessos difusos em modelos animais, resultando em infecção disseminada nos rins e baço (GRENIER e MAYRAND, 1987; NEIDERS et al., 1989; LAINE e VAN WINKELHOFF, 1998; YOSHIMURA et al., 2008), enquanto cepas que não apresentam cápsula causam abscessos localizados e são menos virulentas, causando menor destruição de tecidos moles (DIERICKX et al., 2003). No entanto, deve ser ressaltado, que em modelo de indução de abscesso, diferenças na expressão de fatores de colonização, como características ligadas à interação entre células bacterianas, e as células do hospedeiro, podem ser minimizadas, pois as bactérias são injetadas diretamente nos tecidos ou mantidas em câmeras inseridas no subcutâneo em modelo murino (YOSHIMURA; OHARA; KONDO, et al., 2008).

Em um recente estudo que testou a capacidade de infecção de $P$.gingivalis e mecanismos de defesa pela resposta imune inata, em modelo experimental de Drosophila melanogaster, foi também demonstrado que a cepa capsulada W83 era mais patogênica do que outras cepas não capsuladas, assim como foi relatado em mamíferos (IGBOIN et al., 2011).

A participação da cápsula no desenvolvimento da periodontite pode ser reconhecida por experimentos que demonstraram que camundongos imunizados com antígeno capsular purificado foram protegidos contra a perda óssea quando desafiados com P.gingivalis (GONZALEZ et al., 2003).

Apesar de maior virulência relacionada a cepas capsuladas, outras estruturas também apresentam um papel importante na interação entre a bactéria e as células do hospedeiro como as fímbrias de $P$. gingivalis (NAKAGAWA et al., 2006), que podem não estar presentes nas amostras capsuladas. A amostra W83, capsulada é afimbriada quando cultivada em condições padrões em meios de cultura (GRENIER e MAYRAND, 1987; LAINE e VAN WINKELHOFF, 1998; YOSHIMURA et al., 2008), sendo a sua capacidade de adesão e internalização em células não fagocíticas inferior à da amostra não capsulada e fimbriada ATCC 33277 (DUNCAN; NAKAO; XIE, 1993; UMEDA et al., 2006). A diversidade da fímbria também poderia refletir no potencial patogênico da cepa, embora as diferenças na capacidade de adesão e invasão a células epiteliais apresentadas 
pelas amostras de $P$. gingivalis independam do genótipo fimA da cepa (UMEDA et al., 2006). Dados adicionais sugeriram que estas diferenças seriam devido à variação na capacidade de degradação de componentes de adesão focal das células promovida pelas arg-gingipaínas (NAKAGAWA et al., 2006).

Além das fimbrias, a presença e o tipo de cápsula parecem influenciar positivamente na adesão inicial às células epiteliais da bolsa periodontal (DIERICKX et al., 2003), e negativamente na indução de citocinas pro inflamatórias por fibroblastos desafiados com $P$. gingivalis (BRUNNER et al., 2010).

No presente estudo, foram analisados vinte e seis isolados clínicos e as cepas de referência W83 e ATCC33277 quanto à produção de cápsula. Dezesseis das amostras analisadas, inclusive a cepa W83, apresentaram estrutura semelhante à cápsula ao microscópio óptico (Figura 2). A opção pela análise microscópica foi devida à grande variabilidade dos antígenos capsulares de $P$. gingivalis. Foram relatados seis antígenos capsulares distintos, e um sétimo foi proposto (BRUNNER et al., 2008), sendo que os dados indicam que menos da metade das amostras de $P$. gingivalis $(45,4 \%)$ puderam ser classificadas nos sorotipos K1 a K6, em ensaio de imunodifusão (LAINE et al., 1997). Assim, a detecção da cápsula por exame microscópico de culturas em fase exponencial de crescimento evitaria a não detecção de amostras capsuladas que apresentassem antígenos capsulares ainda não conhecidos.

Alterações da superfície celular induzem a alterações na hidrofobicidade da célula, e as interações hidrofóbicas mediam a adesão de bactérias aos tecidos do hospedeiro (GIBBONS e ETHERDEN, 1983; DAVEY e DUNCAN, 2006). Em muitos sistemas biológicos, a hidrofobicidade é determinada pela composição protéica, sendo dependente da quantidade de aminoácidos hidrofóbicos polares que os constituem (JANDA e ABBOT, 1993). A literatura relata que a cepa não capsulada ATCC 33277 apresenta-se mais hidrofóbica que a cepa capsulada W83 (DAVEY e DUNCAN 2006; WATANABE et al., 1992; GIBBONS e ETHERDEN, 1983). Além disso, mutantes K- obtidas a partir da deleção de genes do lócus de biossíntese capsular em W83 mostraram-se mais hidrofóbicas que a cepa selvagem (DAVEY e DUNCAN, 2006).

Apesar de confirmar os dados apresentados para as cepas de referência, diferindo do resultado esperado, no presente estudo foi observada grande variabilidade na hidrofobicidade de isolados clínicos capsulados e não capsulados 
(Figura 4), sugerindo diferenças nesta propriedade influenciadas por outros fatores além da presença da cápsula. Assim, os dados sugerem que possivelmente a composição de proteínas da membrana externa, apresentando aminoácidos com maior ou menor hidrofobicidade influenciariam mais fortemente na capacidade hidrofóbica da célula do que a presença de cápsula.

O lócus BPC codifica as proteínas necessárias para a biossíntese de cápsula em W83 (DAVEY e DUNCAN, 2006). Mutação no gene PG0106 da cepa capsulada W83 resultou na ausência da produção de cápsula, um fenótipo associado à maior formação de biofilme e erros na síntese do LPS (DAVEY e DUNCAN, 2006). Além disso, amostras não capsuladas, como ATCC 33277 e 381, apresentam deleções/variações em alguns genes deste lócus entre os genes PG0106 a PG0120 apesar do gene pg0106 estar presente também no genoma destas cepas (CHEN et al., 2004; ADUSE e OPOKU et al., 2006).

No presente estudo, a análise de pg0106 foi realizada visando detectar o lócus de biossíntese de polissacarídeos nas amostras, sendo este ensaio inicialmente previsto como um controle. No entanto, a PCR com DNA de amostras de $P$. gingivalis usando iniciadores complementares a pg0106 resultou em amplicons em 22 entre 28 amostras analisadas, capsuladas e não capsuladas (Figura 6). Assim, os dados indicam polimorfismo também no gene pg106 entre amostras capsuladas, já que o gene homólogo a pg0106 de W83 não foi detectado no genoma de 4 amostras capsuladas. Estes dados diferem dos obtidos com análise por hibridização em microarranjo, em que, além de W83, as sete amostras analisadas apresentaram o gene pg106 homólogo a W83, sendo este considerado parte do genoma essencial de $P$. gingivalis. No entanto, neste estudo, apenas uma entre as amostras analisadas não apresentava cápsula (BRUNNER et al., 2010b).

Estudos anteriores demonstraram que o gene pg0111 está ausente no genoma da cepa não capsulada ATCC 33277 e embora presente no genoma da cepa $\mathrm{K}^{-}$381, este apresenta baixa homologia com o de W83 (BRUNNER et al., 2008). O gene pg0111 apresentando complementaridade com os iniciadores desenhados para W83 não foi detectado no genoma de cepas não capsuladas, mas foi detectado em apenas cinco dos isolados que apresentam cápsula (FIGURA 8). Dados anteriores sugeriram que a seqüência do gene pg0111 pode ser extremamente variável (ADUSE-OPOKU et al., 2006), o que foi confirmado neste estudo. Interessantemente, Brunner et al. (2010b) analisando a presença de 
diferentes genes do polissacarídeo capsular através de hibridização, relataram que o gene pg0111 estava presente apenas nas amostras sorotipos K1 e K7. Assim, os cinco isolados clínicos não K1 (não apresentando pg0118) em que este gene foi detectado, possivelmente pertencem ao sorotipo $\mathrm{K} 7$.

$P$. gingivalis sorotipo K1 (cepas W50 e W83) induz a maior expressão de quimiocinas em macrófagos murínicos do que os demais, sugerindo que este polissacarídeo capsular pode ser importante para a interação da bactéria com o hospedeiro (D'EMPAIRE et al., 2006). A detecção de amostras K1 pode ser realizada pela detecção do gene pg0118 usando iniciadores baseados na sequência de W83. (Figura 10) (BRUNNER et al., 2008). No entanto, entre as amostras analisadas, além da cepa de referencia W83, apenas um isolado clínico foi classificado como $K 1$, sugerindo baixa prevalência de cepas $K 1$.

Pouco se conhece sobre a regulação da expressão de genes da cápsula em $P$. gingivalis. Apesar deste estudo não ter como objetivo determinar a prevalência de amostras capsuladas observa-se que grande parte das amostras não expressou cápsula nas condições estudadas. Outros estudos, analisando a expressão de genes do lócus BPC em diferentes amostras são necessários, mas os dados indicam que estes devem ser precedidos de seqüenciamento deste lócus, devido à sua grande variabilidade.

Além da variabilidade de genes do polissacarídeo capsular, um recente estudo demonstrou que uma proteína termoestável denominada $\mathrm{HU}$, cuja função é prevenir a desnaturação do DNA sob condições de stress, poderia estar associada à regulação da transcrição dos genes do lócus do polissacarídeo capsular (ALBERTI-SEGUI et al., 2010). Fatores ambientais, como a presença de derivados do tabaco são capazes de regular negativamente a expressão de cápsula e aumentar a transcrição de genes associados a fímbrias (BAGAITKAR et al., 2010).

Vários estudos têm demonstrado a heterogeneidade das amostras de $P$.gingivalis e sugerem que estas diferenças poderiam refletir o potencial virulento de diferentes clones (NEIDERS et al., 1989; OZMERIÇ et al., 2000; HAMADA et al., 2002; KOEHLER et al., 2003). Diferenças na progressão e severidade da periodontite foram também associadas a diferenças na virulência de cepas de P.gingivalis (KOEHLER et al., 2003; ENERSEN et al., 2006; TEIXEIRA et al., 2009). 
Vários métodos têm sido utilizados para tentar definir clones patogênicos de P.gingivalis. O emprego de técnicas com grande poder de discriminação, baseados em perfis de bandas anônimas como AP-PCR e RAPD (MENARD e MOUTON, 1995), mostraram ausência de um tipo clonal de $P$. gingivalis predominantemente associado à periodontite. Análise por eletroforese de enzimas multilocus (MLEE) também não demonstrou evidências de que determinadas linhagens ou clones de $P$.gingivalis fossem associados com um tipo distinto de infecção e indicaram que os pacientes podem ser infectados com uma ampla variedade de cepas (LOSS et al., 1993).

A análise por MLST implica na demonstração de linhagens filogeneticamente distintas, e por isso é considerada padrão ouro entre os métodos de tipagem. Estudos pioneiros empregando esta técnica em $P$. gingivalis permitiram determinar grande variabilidade entre isolados, sugerindo uma população com intensa recombinação, mas não há relato na literatura sobre características fenotípicas das amostras (FRADSEN et al., 2001; KOEHLER et al., 2003). Mais recentemente, Enersen et al. (2008), analisaram a distribuição dos genótipos fimA em isolados clínicos de P.gingivalis e concluíram que P. gingivalis apresenta uma estrutura fracamente clonal, havendo relação entre o genótipo fimA e o ST (sequence type), que uma tendência em agrupar os genótipos fimA em grupos filogenéticos distintos.

No presente estudo, encontramos 18 novos STs e 17 seqüências alélicas que não estavam descritas no banco de dados, indicando alelos novos. A análise do número de diferentes e novos alelos encontrados neste estudo, mostrou que o gene fts $Q$ apresentou o maior número de alelos, como havia sido demonstrado em estudos anteriores (ENERSEN et al., 2006, 2008). Por outro lado, o gene ftsQ é altamente conservado em diferentes linhagens de outras espécies bacterianas como Eschechia coli e Yersinia enterocolitica, desempenhando um importante papel na montagem de proteínas de divisão celular (VAN DEN ENT et al., 2008; GRENGA et al., 2010). Outros genes analisados no presente estudo mostraram uma menor variabilidade em relação ao número de diferentes e novos alelos na população de P.gingivalis, como recA e pepO. Alguns estudos tem demonstrado, que o gene recA não está relacionado apenas a reparação do DNA, mas pode estar relacionado com a ativação de outros genes que controlam a auto-agregação e a hemaglutinação (ABAIBOU, 2000). Os autores ainda mencionam que, provavelmente, o operon $\operatorname{rec} A$ possa controlar vários fatores de virulência, visto 
que uma cepa W83 deficiente em recA mostrou redução em sua capacidade de virulência quando inoculada em camundongo. Interessantemente, Enersen et al., (2008), relataram o aparecimento de alelos diferentes para os genes recA e pepO em amostras de diferentes sítios de um mesmo paciente, sugerindo que estes genes podem ser mais susceptíveis à recombinação, e que pequenas variações na sequência de nucleotídeos resultantes dos eventos de recombinação ocorrem em um determinado sitio periodontal.

O gene hag $B$ apresentou variabilidade dentro da faixa dos demais genes de manutenção analisados (12 alelos). No entanto, a sua utilização nas análises de MLST pode ser questionada, visto que este codifica uma proteína relacionada à hemaglutinação, não sendo este um evento considerado essencial ao metabolismo bacteriano. De fato, hagB foi associado com a virulência de P.gingivalis, relacionado com a evasão no sistema imune e adesão a células endoteliais (ENERSEN et al., 2006; BRUNNER et al., 2010; DOLGILEVICH et al., 2011).

Estes dados sugerem que a capacidade de descriminação de cada gene no MLST pode variar de acordo com a população estudada. Assim, os dados do presente estudo indicam que a variabilidade dos genes relacionados à manutenção (housekeeping) aqui analisados permitiram a análise filogenética. Mas, é importante ressaltar que a variabilidade observada nestes genes não deve influenciar na tradução da proteína (MAIDEN et al., 1998).

A análise do dendrograma obtido a partir da matriz de similaridade das seqüências de genes de manutenção mostrou a grande variabilidade associada aos isolados de $P$.gingivalis e permitiu dividir a população de $P$.gingivalis analisada em três grandes grupos denominados I, II e III, com similaridade maior que 30\% dentro de cada grande grupo, indicativa de estrutura populacional fracamente clonal, como observado por Enersen et al. (2008).

O presente estudo mostrou que não houve uma associação clara entre a presença de cápsula e os grupos filogenéticos. Por outro lado, quando comparados os diferentes grupos e subgrupos quanto à hidrofobicidade, observa-se que amostras do mesmo ST ou relacionadas apresentaram capacidade hidrofóbica similar. Além disso, as amostras classificadas no grupo III apresentaram valores semelhantes e menor porcentagem de hidrofobicidade quando comparadas aos outros grupos. Assim, os dados sugerem tendência de relação entre 
hidrofobicidade e a distribuição no dendrograma. Destaca-se que não foi observada clara associação entre a presença ou ausência de cápsula e a hidrofobicidade, ao contrário do demonstrado para a cepa W83 e sua mutante K- (DAVEY e DUNCAN, 2006), sugerindo que aminoácidos hidrofóbicos na superfície da célula, e não apenas a presença de cápsula poderiam estar influenciando na hidrofobicidade.

Diferindo de outros patógenos capazes de colonizar o ambiente e superfícies mucosas, como E. coli e Pseudomonas, que apresentam patovars bastante distintos (KUNG et al., 2010; SCHMIDT, 2010), P. gingivalis apresentou estrutura fracamente clonal, e não houve relação entre os grupos filogenéticos e a presença de um importante fator de virulência como a cápsula. $P$. gingivalis coloniza apenas as superfícies mucosas, de maneira similar a Helicobacter pylori, cujas freqüentes recombinações entre múltiplas amostras pode ocorrer durante a colonização na mucosa gástrica (FALUSH et al., 2001). De acordo com diferentes autores, a bolsa periodontal pode ser um ambiente favorável para a transferência horizontal de genes e para que ocorra recombinação entre cepas de P.gingivalis (YOSHIMOTO et al., 1993; KOEHLER et al., 2003). Estes autores de detectaram intensa recombinação entre amostras obtidas de sítios periodontais diferentes mas de um mesmo paciente, portanto este estudo encontrou estrutura populacional panmítica para os 19 isolados de P.gingivalis. Outros estudos também relataram as altas taxas de recombinação que resultam na plasticidade observada no genoma de P.gingivalis, através de PFGE (PEREZ-CHAPARRO et al., 2009). No presente estudo foram analisados apenas dois pares de amostras originadas no mesmo paciente, $381 \mathrm{~A} / 381 \mathrm{C}$ e 268A1 / 268A2. Estas amostras foram analisadas porque embora apresentassem o mesmo genótipo $\operatorname{fim} A$, uma delas apresentava cápsula, enquanto a segunda não. Apesar desta diferença no fenótipo, os pares apresentaram o mesmo ST, e no par 268A1/268A2 foi também determinada diferença na deteç̧ão do gene pg0106. Estes dados poderiam indicar que a expressão da cápsula nestas amostras teria sido alterada por rearranjos no cromossomo bacteriano. Esta hipótese deve ser melhor analisada em estudos futuros.

No presente estudo foram comparados os diferentes grupos filogenéticos com diferentes genótipos $\operatorname{fimA}$, a presença de cápsula, capacidade hidrofóbica e detecção de genes do polissacarídeo capsular. Observa-se nos dados apresentados certa relação entre genes do lócus $B P C$ e a estrutura filogenética, 
reforçando observações de que $P$. gingivalis apresenta uma estrutura populacional fracamente clonal.

Observou-se que o gene pg0106 homólogo a W83 e ATCC 33277 foi detectado em todas as amostras dos grupos I e III, enquanto as amostras do grupo II, independentemente da presença de cápsula, apresentaram ou não este gene. É interessante notar que a única amostra do subgrupo E a não apresentar pg0106 foi a amostra P986, que difere das demais deste subgrupo em cerca de $40 \%$. Três das cinco amostras do subgrupo D não apresentam o gene pg0106 homólogo às demais. As duas amostras restantes cujo DNA não resultou em amplicom para pg0106 na PCR não puderam ser tipadas por MLST, apesar de terem sido classificadas como $P$. gingivalis por análise com iniciadores espécie específicos para $P$. gingivalis, complementares a 16SrRNA. Maiores estudos com estas amostras são necessários para estabelecimento da sua identificação definitiva. Assim, os dados sugerem que, diferindo dos dados apresentados por Brunner et al., 2010, o gene pg106 não faria parte do genoma essencial de $P$. gingivalis, podendo estar ausente em amostras do grupo filogenético II deste estudo.

Além disso, as amostras do grupo $\mathrm{K} 1$, representadas por um único $\mathrm{ST}$, pertencente ao grupo filogenético I, foram homogêneas quanto a expressão de cápsula, hidrofobicidade e genéotipo fimA. No entanto, as amostras cujo DNA resultou em amplificação do gene pg0111, e não de pg0118, possivelmente pertencentes ao tipo K7 (BRUNNER et al., 2010), foram distribuídas nos grupos filogenéticos II , III e não tipável, o que sugere que estas apresentam muitas características que as distinguem.

A distribuição de cepas capsuladas e não capsuladas independente da relação filogenética entre as amostras, e a detecção de genes associados à cápsula deixam claro que o lócus BPC é bastante diverso em $P$. gingivalis.

Os dados da análise filogenética confirmam estudo prévio em que as amostras ATCC 33277 e W83 também haviam sido classificadas no mesmo grupo (ENERSEN et al., 2008), composto principalmente por amostras dos tipos fimA II e IV . No entanto, diferindo deste estudo, nossos dados indicam que a maior parte das amostras dos tipos fimA I e lb pertencem a linhagens filogenéticas distintas às dos genótipos fimA II. Ogenótipo fimA II foi associado ao grupo filogenético II e apenas uma amostra deste genótipo (322B1) foi associada ao grupo filogenético III, enquanto os genótipos fimA I e lb foram mais comumente classificados no grupo I. 
Deve ser ressaltado, no entanto, que o grupo filogenético III foi formado por amostras classificadas nos genótipos fimA I, lb e II, enquanto amostras do genótipo fimA IV foram classificadas nos grupos filogenéticos I e II. Estudo analisando as sequências dos genes fim $A$ demonstrou claramente a maior similaridade entre fim $A$ I e lb do que entre estas e fimA II, sendo que fimA IV é o mais distante geneticamente entre os genes $\operatorname{fim} A$ analisados (ENERSEN et al., 2008). Além disso, os mesmos autores demonstraram que fimA é bastante conservado, e sugerem que poucas recombinações são observadas nestes genes.

Deve ser ressaltado, no entanto, que a tipagem baseada na PCR de fimA (AMANO et al., 2000) é sujeita a erros, e que cepas classificadas em um genótipo, com o emprego dos iniciadores tipo específicos, podem eventualmente ser classificadas em outro tipo $\operatorname{fim} A$ pela análise das sequências deste gene (ENERSEN et al., 2008).

Assim, os dados do estudo filogenético sugerem que amostras fimA II, e fimA I / lb representam grupos distintos, sendo possivelmente mais similares também em outras características fenotípicas. Estudos anteriores demonstraram que amostras do tipo II são mais prevalentes em pacientes com periodontite (AMANO et al., 2000; MISSAILIDIS et al., 2004; ENERSEN et al., 2008) e estudos com fímbrias purificadas sugerem que o tipo II seja mais invasivo em células epiteliais que os demais tipos (NAKAGAWA et al., 2002). Cepas do genótipo II possuem capacidade de degradar moléculas sinalizadoras relacionadas a integrina, paxilina e quinase de adesão focal (FAK), prejudicando assim a migração e proliferação celular (AMANO et al., 2007). A substituição da fímbria tipo I pela fimbria do tipo II aumentou a adesão e invasão da amostra em células epiteliais (KATO et al., 2007). Em modelo de abscesso em ratos, a amostra fimA II resultou em maior resposta inflamatória do que os demais genótipos, sugerindo que a fímbria tipo II é um determinante crítico da virulência de $P$. gingivalis (KATO et al., 2007).

Por outro lado, amostras consideradas altamente patogênicas em animais experimentais, como W83 e W50, pertencem ao genótipo fimA IV embora não expressem a fimbria nas condições estudadas (GENCO et al., 1991). É importante observar que quatro de cinco cepas do genótipo fimA IV foram capsuladas neste estudo. Este genótipo possivelmente é heterogêneo quanto a outras 
características, visto que as suas amostras são igualmente distribuídas entre os grupos filogenéticos I e II.

O grupo filogenético III apresentou a maior distância genética em relação aos demais, e foi composto por amostras dos genótipos I, Ib e II, todas oriundas do Brasil. Maiores estudos são necessários para comparar o fenótipo entre os isolados deste grupo e dos demais. O estudo de core genoma e pan genoma realizado em $P$. gingivalis, até o momento (BRUNNER et al., 2010b), não determinou a estrutura filogenética das amostras analisadas, mas baseou-se no tipo capsular para selecionar as amostras analisadas. Resultados deste estudo, como considerar o gene pg0106 como parte do genoma essencial, podem ser contestados pelas análises aqui apresentadas. Ainda, as amostras de $P$. gingivalis com genoma conhecido até o momento são W83 e ATCC 33277, ambas classificadas no mesmo grupo filogenético, sugerindo que outros genes acessórios poderiam ser descritos pela análise de cepas pertencentes a outros grupos filogenéticos. P. gingivalis é considerado como apresentando fraca estrutura clonal (ENERSEN et al., 2008). Assim, seria recomendável que outras amostras pertencentes aos demais grupos filogenéticos fossem analisadas, não somente em relação ao genoma, mas quanto ao transcriptoma e fenótipo.

Os dados apresentados neste estudo demonstraram grande prevalência de cepas capsuladas entre os isolados de P.gingivalis analisados, distribuídas em todos os grupos filogenéticos. O lócus de síntese de polissacarídeo capsular mostrou-se bastante diverso. Houve tendência de associação entre o polimorfismo de $B P C$ e genótipo fimA com os diferentes grupos filogenéticos de $P$. gingivalis . 


\section{CONCLUSÕES}

Baseados nas condições empregadas no presente estudo, os dados obtidos sugerem:

1. As cepas capsuladas são prevalentes entre isolados de P.gingivalis e não há relação entre capacidade hidrofóbica e produção de cápsula.

2. Os genes do lócus biossíntese do polissacarídeo capsular apresentam grande variabilidade, e a baixa deteç̧ão do gene pg0118 indica baixa prevalência de cepas do sorotipo capsular K1. A detecção do gene pg0106 não foi associada a presença da cápsula, mas este parece não fazer parte do genoma essencial de P.gingivalis.

3. A análise filogenética indicou que as amostras de $P$. gingivalis são distribuídas em três grandes grupos, e que houve tendência de associação entre o polimorfismo do lócus BPC e o genotipo fimA, com os diferentes grupos filogenéticos, mas não a relação entre a presença de cápsula e os grupos filogenéticos. 


\section{REFERÊNCIAS*}

ABAIBOU, H.; MA, Q.; OLANGO, G. J.; POTEMPA, J.; TRAVIS, J.; FLETCHER, H. M. Unaltered expression of the major protease genes in a non-virulent recAdefective mutant of Porphyromonas gingivalis W83.Oral Microbiol. Immunol., v. 15, p.40-47, 2000.

ADUSE-OPOKU, J.; SLANEY, J. M.; HASHIM, A.; GALLAGHE, A.; RANGARAJAN, M.; BOUTAGA, K.; LAINE, M. L.; VAN WINKELHOFF, A. J.; CURTIS, M. A. Identification and Characterization of the Capsular Polysaccharide (K-Antigen) Locus of Porphyromonas gingivalis. Infection. Immunity., v. 74, p. 449-460, 2006.

ALBERTI-SEGUI, C.; ARNDT, A.; CUGINI, C.; PRIYADARSHINI, R.; DAVEY, M. E. $\mathrm{HU}$ protein affects transcription of surface polysaccharide synthesis genes in Porphyromonas gingivalis. J. Bacteriol., v. 192, p. 6217-6229, 2010.

AMANO, A.; NAKAGAWA, I.; OKAHASHI, N.; HAMADA, N. Variations of Porphyromonas gingivalis fimbriae in relation to microbial pathogenesis. $J$. Periodontal. Res., v. 39, p.136-142, 2004.

AMANO A. Molecular interaction of Porphyromonas gingivalis with host cells: implication for the microbial pathogenesis of periodontal disease. J. Periodontol., v. 74, p.90-96, 2003.

AMANO, A.; NAKAGAWA, I.; KATAOKA, K.; MORISAKI, I.; HAMADA S. Distribution of Porphyromonas gingivalis strains fimA genotypes in periodontitis patients. J. Clin. Microbiol., v. 37, p. 1426-1430, 1999.

AMANO, A.; KUBONIWA, M.; NAKAGAWA, I.; AKIYAMA, S.; MORISAKI, I.; HAMADA, S. Prevalence of specific genotypes of Porphyromonas gingivalis fimA and periodontal health status. J. Dent. Res., v. 79, p. 1664-1668, 2000.

AMANO, A.; PREMARAJ, T.; KUBONIWA, M.; NAKAGAWA, I. Altered antigenicity in periodontitis patients and decreased adhesion of Porphyromonas gingivalis by environmental temperature stress. Oral Microbiol. Immunol., v. 16, p. 124-128, 2001.

AMANO, A.; NAKAGAWA, I.; KATAOKA, K.; MORISAKI, I.; HAMADA S. Distribution of Porphyromonas gingivalis strains fimA genotypes in periodontitis patients. J. Clin. Microbiol., v. 37, p. 1426-1430, 1999.

AMANO, A. Disruption of epithelial barrier and impairment of cellular function by Porphyromonas gingivalis. Front. Biosci., v.1, p.3965-3974, 2007.

*De acordo com:

ASSOCIAÇÃO BRASILEIRA DE NORMAS TÉCNICAS. NBR 6023: informação e documentação: referências: elaboração. Rio de Janeiro, 2002. 
BAGAITKAR, J.; DEMUTH, D. R.; SCOTT, D. A. Tobacco use increases susceptibility to bacterial infection. Tob. Induc. Dis., v. 4, p. 4-12, 2008.

BAGAITKAR, J.; DEMUTH, D. R.; DAEP, C. A.; RENAUD, D. E.; PIERCE, D. L.; SCOTT, D.A. Tobacco upregulates $P$. gingivalis fimbrial proteins which induce TLR2 hyposensitivity. PLoS One., v. 5, p. 1-11, 2010.

BARNARD, P. National Oral Health Survey Australia 1987-88. Canberra: Australian Government Printing Services, 1993.

BECK, J.; GARCIA, R.; HEISS, G.; VOKONAS, P. S.; OFFENBACHER, S. Periodontal disease and cardiovascular disease. J. Periodontol., v. 67, p. 11231137, 1996.

BERRY, D. S.; LYNN, F.; LEE, C. H; FRASCH, C. E.; BASH, M. C. Effect of O acetylation of Neisseria meningitidis serogroup A capsular polysaccharide on development of functional immune responses. Infect. Immun., v.70, p.3707-3713, 2002.

BONASS, W. A.; MARSH, P. D.; PERCIVAL, R. S.; ADUSE-OPOKU, J.; HANLEY, S. A.; DEVINE, D. A.; CURTIS, M. A. Identification of rag AB as a temperatureregulated operon of Porphyromonas gingivalis W50 using differential display of randomly primed RNA. Infect. Immun., v. 68, p. 4012-4017, 2000.

BOTTA, G. A.; ARZESE, A.; MINISINI, R.; TRANI, G. Role of structural and extracellular virulence factors in gram-negative anaerobic bacteria. Clin. Infect. Dis., v. 18, p. 260-264, 1994.

BRUNNER, J.; SCHERES, N.; EL IDRISSI, N. B.; DENG, D. M.; LAINE, M. L; VAN WINKELHOFF, A. J.; CRIELAARD, W. The capsule of Porphyromonas gingivalis reduces the immune response of human gingival fibroblasts. BMC Microbiol., $v$. 10 , p. 1-11, 2010a.

BRUNNER, J.; WITTINK, F. R.; JONKER, M. J.; DE JONG, M.; BREIT, T.M.; LAINE, M.L.; DE SOET, J. J.; CRIELAARD, W. The core genome of the anaerobic oral pathogenic bacterium Porphyromonas gingivalis. BMC Microbiol., v.10, p.1-13, $2010 b$.

BRUNNER, J.; CRIELAARD, W.; VAN WINKELHOFF, A. J. Analysis of the capsular polysaccharide biosynthesis locus of Porphyromonas gingivalis and development of a K1-specific polymerase chain reaction-based serotyping assay. J. Periodontal. Res., v. 43, p. 698-705, 2008.

BYRNE, S. J.; DASHPER, S. G.; DARBY, I. B.; ADAMS, G. G.; HOFFMANN, B.; REYNOLDS, E. C. Progression of chronic periodontitis can be predicted by the levels of Porphyromonas gingivalis and Treponema denticola in subgingival plaque. Oral Microbiol. Immunol., v. 24, p. 1-9, 2009.

COOPER, E.; FEIL J. Mulrilocus sequence typing- what is resolved. Trends in Microbiol., v. 12, p. 373-377, 2004. 
CHATZIDAKI-LIVANIS, M.; COYNE, M. J.; ROCHE-HAKANSSON, $\quad \mathrm{H}$.; COMSTOCK, L. E. Expression of a uniquely regulated extracellular polysaccharide confers a large capsule phenotype to Bacteroides fragilis. J. Bacteriol., v. 3, p. 1020-1026, 2008.

CHEN, T.; HOSOGI, Y.; NISHIKAWA, K.; ABBEY, K.; FLEISCHMANN, R. D.; WALLING, J.; DUNCAN, M.J. Comparative whole-genome analysis of virulent and avirulent strains of Porphyromonas gingivalis. J. Bacteriol. v. 186, p. 5473-5479, 2004.

CHEN, W.; PALMER, R. J.; KURAMITSU, H. K. Role of polyphosphate kinase in biofilm formation by Porphyromonas gingivalis. Infect. Immun., v. 70, p. 4708-4715, 2002.

CHOI, J. I.; SCHIFFERLE, R. E.; YOSHIMURA, F.; KIM, B. W. Capsular polysaccharide-fimbrial protein conjugate vaccine protects against Porphyromonas gingivalis infection in SCID mice reconstituted with human peripheral blood Iymphocytes. Infect. Immun., v. 66, p. 391-393, 1998.

DAGAN, R.; KAYHTY, H.; WUORIMAA, T.; YAICH, M.; BAILLEUX, F.; ZAMIR, O.; ESKOLA, J. Tolerability and immunogenicity of an eleven valent mixed carrier Streptococcus pneumoniae capsular polysaccharide-diphtheria toxoid or tetanus protein conjugate vaccine in Finnish and Israeli infants. Pediatr. Infect. Dis. J.,v. 23, p. 91- 98, 2004.

DARVEAU, R.P.; TANNER, A.; PAGE, R.C. The microbial challenge in periodontitis. Periodontol. 2000., v. 14, p. 12-32, 1997.

DASHPER, S. G.; ANG, C. S.; VEITH, P. D.; MITCHELL, H. L.; LO, A. W.; SEERS, C. A.; WALSH, K. A.; SLAKESKI, N.; CHEN, D.; LISSEL, J. P.; BUTLER, C. A.; O'BRIEN-SIMPSON, N.M.; BARR, I.G.; REYNOLDS, E.C. Response of Porphyromonas gingivalis to heme limitation in continuous culture. J. Bacteriol., v. 191, p. 1044-1055, 2009.

DAVENPORTE, S.; WILLIAMS, C. E.; STERNE, J. A.; MURAD, S.; SIVAPATHASUNDRAM, V.; CURTIS, M. A. Maternal periodontal disease and preterm low birthweight: case-control study. J. Dent. Res., v. 81, p. 313-318, 2002.

DAVEY, M. E.; DUNCAN, M. J. Enhanced biofilm formation and loss of capsule synthesis: deletion of a putative glycosyltransferase in Porphyromonas gingivalis. $\mathbf{J}$. Bacteriol., v. 188, p. 5510-5523, 2006.

D'EMPAIRE, G.; BAER, M. T.; GIBSON, F. C. The K1 serotype capsular polysaccharide of Porphyromonas gingivalis elicits chemokine production from murine macrophages that facilitates cell migration. Infect. Immun., v. 74, p. 62366243, 2006. 
DIERICKX, K.; PAUWELS, M.; LAINE, J.; VAN ELDERE, J. J. Adhesion of Porphyromonas gingivalis serotypes to pocket epithelium. J. Periodontol., v. 74, p. 844-848, 2003.

DOETSH, R. N. Determinative methods of light microscopy. In: GERHARDT, P. (Ed.). Manual of methods for general bacteriology. Washington: American Society for Microbiology, 1981. p. 29.

DOLGILEVICH, S.; RAFFERTY, B.; LUCHINSKAYA, D.; KOZAROV, E.Genomic comparison of invasive and rare non-invasive strains reveals Porphyromonas gingivalis genetic polymorphisms. J. Oral Microbiol., v.10, p.12-14, 2011.

DUNCAN, M. J.; NAKAO, Z.; XIE, H. Interactions of Porphyromonas gingivalis with epithelial cells. Infect. Immun., v. 61, p. 2260-2265, 1993.

EGLAND, P. G.; PALMER JR, R. J.; KOLENBRANDER, P. E. Interspecies communication in Streptococcus gordonii-Veillonella atypica biofilms: signaling in flow conditions requires juxtaposition. Proc. Natl. Acad. Sci., v. 101, p. 1691716922, 2004.

ENERSEN, M.; OLSEN, I.; VAN WINKELHOFF, A. J.; CAUGANT, D. A. Multilocus sequence typing of Porphyromonas gingivalis strains from different geographic origins. J. Clin. Microbiol., v. 44, p. 35-41, 2006.

ENERSEN, M.; OLSEN, I.; KVALHEIM, O.; CAUGANT, D.A. fimA Genotypes and Multilocus Sequence Types of Porphyromonas gingivalis from Patients with Periodontitis. J. Clin. Microbiol., v. 40, p. 31-42, 2008.

FALUSH, D.; KRAFT, C.; TAYLOR, N.S.; CORREA, P.; FOX, J. G.; ACHTMAN, M.; SUERBAUM, S. Recombination and mutation during long-term gastric colonization by Helicobacter pylori: estimates of clock rates, recombination size, and minimal age.Proc. Natl. Acad. Sci. U S A. v. 98, p. 15056-15061, 2011.

FRADSEN, E. V. G.; POULSEN, K.; CURTIS, M. A.; KILLIAN, M. Evidence of recombination in Porphyromonas gingivalis and random distribution of putative virulence markers. Infect. Immun., v. 69, p. 4479-4485, 2001.

GENCO, C.A.; CUTLER, C,W; KAPCZYNSKI, D., MALONEY, K. ; ARNOLD, R.R. A novel mouse model to study the virulence of and host response to Porphyromonas (Bacteroides) gingivalis. Infect. Immun., v.59, p.255-263,1991.

GIBBONS, R. J.; ETHERDEN, I. Comparative hydrophobicities of oral bacteria and their adherence to salivary pellicles. Infect. Immun., v. 41, p. 1190-1196, 1983.

GONZALEZ, D.; TZIANABOS, A. O.; GENCO, C. A.; GIBSON, F. C. Immunization with Porphyromonas gingivalis capsular polysaccharide prevents $P$. gingivaliselicited oral bone loss in a murine model. Infect. Immun., v. 71, p. 2283-2287, 2003. 
GRENIER, D.; MAYRAND, D. Selected characteristics of pathogenic and nonpathogenic strains of Bacteroides gingivalis .J. Clin. Microbiol., v. 25, p. 738740, 1987.

GRENGA, L.; GUGLIELMI, G.; MELINO, S.; GHELARDINI, P.; PAOLOZZI, L.FtsQ interaction mutants: a way to identify new antibacterial targets. N. Biotechnol., $\mathrm{V}$. 27 , p. $870-871,2010$.

GRIFFEN, A. L.; LYONS, S. R.; BECKER, M. R.; MOESCHBERGER, M. L.; LEYS, E. J. Porphyromonas gingivalis strain variability and periodontitis. J. Clin. Microbiol., v. 37, p. 4028-4033, 1999.

HAFFAJEE, A. D.; CUGINI, M. A.; TANNER, A.; POLLACK, R. P. Subgingival microbiota in healthy, well-maintained elder and periodontitis subjects. J. Clin. Periodontol., v. 25, p. 346-353, 1998.

HAFFAJEE, A. D.; SOCRANSKY, S. S. Microbial etiological agents of destructive periodontal diseases. Periodontol 2000, v. 5, p. 78-111, 1994.

HAFFAJEE, A. D.; SOCRANSKY, S. S. Microbiology of periodontal diseases: introduction. Periodontology, v. 38, p. 9-12, 2005.

HAMADA, S.; AMANO, A.; KIMURA, S.; NAKAGAWA, I.; KAWABATA, S.; MORISAKI, I. The importance of fimbriae in the virulence and ecology of some oral bacteria. Oral Microbiol. Immunol., v. 13, p. 129-138, 1998.

HASEGAWA, Y.; NISHIYAMA, S.; NISHIKAWA, K.; KADOWAKI, T.; YAMAMOTO, K.; NOGUCHI, T.; YOSHIMURA, F. A novel type of two-component regulatory system affecting gingipains in Porphyromonas gingivalis. Microbiol. Immunol., v. 47, p. 849-858, 2003.

HASEGAWA, Y.; TRIBBLE, G. D.; BAKER, H. V.; MANS, J. J.; HANDFIELD, M.; LAMONT, R.J. Role of Porphyromonas gingivalis SerB in gingival epithelial cell cytoskeletal remodeling and cytokine production. Infect. Immun., v. 76, p. 24202427, 2008.

HASHIMOTO, M.; OGAWA, S.; ASAI, Y.; TAKAI, Y.; OGAWA, T. Binding of Porphyromonas gingivalis fimbriae to Treponema denticola dentilisin.FEMS Microbiol. Lett., v.226, p. 267-271, 2003.

HENGARTNER, M. O.; BRYANT, J. A. Apoptotic cell death: from worms to wombats ... but what about the weeds? Symp. Soc. Exp. Biol. v. 52, p. 1-12, 2000.

HILTON, T.; ROSCHE, T.; FROELICH, B.; SMITH, B.; OLIVER, J. Capsular polysaccharide phase variation in Vibrio vulnificus. Appl. Environ. Microbiol., v. 11, p. 6986-6993, 2006.

HIROI, M.; SHIMOJIMA, T.; KASHIMATA, M.; MIYATA, T.; TAKANO, H.; TAKAHAMA, M.; SAKAGAMI, $\mathrm{H}$. Inhibition by Porphyromonas gingivalis LPS of 
apoptosis induction in human peripheral blood polymorphonuclear leukocytes. Anticancer Res., v. 5A, p. 3475-3479, 1998.

HOLT, S.; EBERSOLE, J. Porphyromonas gingivalis, Treponema denticola, and Tannerella forsythia: the "red complex," a prototype polybacterial pathogenic consortium in periodontitis. Periodontol. 2000, v. 38, p. 72-122, 2005.

HOLT, S. C. J.; EBERSOLE, J.; FELTON, M.; BRUNSVOLD, E.; KORNMAN, K. S. Implantation of Bacteroides gingivalis in nonhuman primates initiates progression of periodontitis. Science, v. 239, p. 55-57, 1988.

HOLT, S. C.; KESAVALU, L.; WALKER, S.; GENCO, C. A. Virulence factors of Porphyromonas gingivalis. Periodontology, v. 20, p. 168-238, 1999.

IGBOIN, C. O.; TORDOFF, K.P.; MOESCHBERGER, M.L.; GRIFFEN, A.L.; LEYS, E.J. Porphyromonas gingivalis-host interactions in a Drosophila melanogaster model. Infect Immun., v. 79, p. 449-458, 2011.

INABA, H.; NAKANO, K.; KATO, T. A. Heterogenic virulence and related factors among clinical isolates of Porphyromonas gingivalis with type II fimbriae. Oral Microbiol. Immunol, v. 23, p. 29-35, 2008.

JANDA, M. J.; ABBOT, S. L. Microbiological hidrophobicity- the sticky end of things. Clin. Microbiol. Newslett., v. 15, p. 9-12, 1993.

KATO, T.; KAWAI, S.; NAKANO, K.; INABA, H.; KUBONIWA, M.; NAKAGAWA, I.; TSUDA, K.; OMORI, H.; OOSHIMA, T.; YOSHIMORI, T.; AMANO, A. Virulence of Porphyromonas gingivalis is altered by substitution of fimbria gene with different genotype. Cell Microbiol., v. 9, n. 3, p.753-765, 2007

KATZ, J.; WARD, D. C.; MICHALEK, S. M. Effect of host responses on the pathogenicity of strains of Porphyromonas gingivalis. Oral Microbiol. Immunol., v.11, p. 309-318, 1996.

KOEHLER, A.; KARCH, H.; BEIKLER, T.; FLEMMIG, T. F.; SUERBAUM, S.; SCHMIDT, $\mathrm{H}$. Multilocus sequence analysis of Porphyromonas gingivalis indicates frequent recombination. Microbiology, v. 149, p. 2407-2415, 2003.

KOLENBRANDER, P. E.; ANDERSON, R. N. Inhibition of coaggregation between Fusobacterium nucleatum and Porphyromonas (Bacteroides) gingivalis by lactose and related sugars. Infect Immun., v. 57, p. 3204-3209, 1989.

KRINOS, C. M.; COYNE, M. J.; WEINACHT, K. G.; TZIANABOS, A. O.; KASPER, D. L.; COMSTOCK, L. E. Extensive surface diversity of a commensal microorganism by multiple DNA inversions. Nature, v. 6863, p. 555-558, 2001.

KUBONIWA, M.; AMANO, A.; INABA, H.; HASHINO, E.; SHIZUKUISHI, S. Homotypic biofilm structure of Porphyromonas gingivalis is affected by FimA type variations. Oral Microbiol. Immunol., v. 3, p. 260-263, 2009. 
KUNG, V. L.; OZER, E. A.; HAUSER, A. R. The accessory genome of Pseudomonas aeruginosa. Microbiol. Mol. Biol. Rev., v. 74, p. 621-641, 2010.

LAINE, M. L.; VAN WINKELHOFF, A. J. Virulence of six capsular serotypes of Porphyromonas gingivalis in a mouse model. Oral Microbiol. Immunol., v. 13 p. 322-325, 1998.

LAINE, M. L.; APPELMELK, B. J.; VAN WINKELHOFF, A. J. Novel polysaccharide capsular serotypes in Porphyromonas gingivalis. J. Periodontal. Res., v. 31 p. 278284, 1996.

LAINE, M.L.; APPELMELK, B. J.; VAN WINKELHOFF, A. J. Prevalence and distribution of six capsular serotypes of Porphyromonas gingivalis in periodontitis patients. J. Dent. Res., v.76; p.1840-1844, 1997.

LAMONT, R. J.; CHAN, A.; BELTON, C. M.; IZUTSU, K. T.; VASEL, D.; WEINBERG, A. Porphyromonas gingivalis invasion of gingival epithelial cells. Infect. Immun. v. 63, p. 3878-3885, 1995.

LAMONT, R. J.; JENKINSON, H. F. Subgingival colonization by Porphyromonas gingivalis. Oral Microbiol. Immunol., v. 6, p. 341-349, 2000.

LAMONT. R. J.; EL-SABAENY, A.; PARK, Y.; COOK, G. S.; COSTERTON, J.W.; DEMUTH, D.R. Role of the Streptococcus gordonii SspB protein in the development of Porphyromonas gingivalis biofilms on streptococcal substrates. Microbiology, v. 148, p. 1627-1636, 2002.

LAMONT, R. J.; JENKINSON, H. F. Life below the gum line: pathogenic mechanisms of Porphyromonas gingivalis. Microbiol. Mol. Biol. Rev., v. 62, p. 1244-1263, 1998.

LEDDER, R. G.; GILBERT, P.; HUWS, S. A.; AARONS, L.; ASHLEY, M. P.; Hull, P. S.; MCBAIN, A. J. Molecular analysis of the subgingival microbiota in health and disease. Appl. Environ. Microbiol., v. 73, p. 516-523, 2007.

LEE, J. C.; LEE, C. Y. Capsular polysaccharides of Staphylococcus aureus, In J. B. Goldberg (ed.), Genetics of bacterial polysaccharides, p.185-205 1999.

LEE, J. Y.; SOJAR, H. T.; BEDI, G. S.; GENCO, R. J. Porphyromonas gingivalis fimbrilin: size, amiino terminal sequence, and antigenic heterogeneith. Infect. Immun., v. 59, p. 383-389, 1991.

LIAO, F.; LI, Z.; WANG, Y.; SHI, B.; GONG, Z.; CHENG, X. Porphyromonas gingivalis may play an important role in the pathogenesis of periodontitis-associated rheumatoid arthritis. Med. Hypotheses, v. 72, p. 732-735, 2009.

MAEDA, K.; NAGATA, H.; KUBONIWA, M.; KATAOKA, K.; NISHIDA, N.; TANAKA, M.; SHIZUKUISHI, S. Characterization of binding of Streptococcus oralis glyceraldehyde-3-phosphate dehydrogenase to Porphyromonas gingivalis major fimbriae. Infect. Immun., v. 72, p. 5475-5477, 2004. 
Maiden MC, Bygraves JA, Feil E, Morelli G, Russell JE, Urwin R, Zhang Q, Zhou J, Zurth K, Caugant DA, Feavers IM, Achtman M, Spratt BG. multilocus sequence typing: a portable approach to the identification of clones within populations of pathogenic microorganisms. Proc. Natl. Acad. Sci. U S A., v. 95, p. 3140-3145, 1998.

MAO, S.; PARK, Y.; HASEGAWA, Y.; TRIBBLE, G.D.; JAMES, C.E.; HANDFIELD, M.; STAVROPOULOS, M.F.; YILMAZ, O.; LAMONT, R.J. Intrinsic apoptotic pathways of gingival epithelial cells modulated by Porphyromonas gingivalis. Cell Microbiol., v. 9, p. 1997-2007, 2007.

MCKEE, A. S.; MCDERMID, A. S.; BASKERVILLE, A.; DOWSETT, A. B; ELLWOOD, D.C.; MARSH, P.D. Effect of hemin on the physiology and virulence of acteroides gingivalis W50. Infect. Immun., v. 52, p. 349-355, 1986.

MEKALANOS, J. J. Enviromental signals controlling expression of virulence determinants in bacteria. J. Bacteriol., v. 174, p. 1-7, 1992.

MENARD, C.; MOUTON, C. Clonal diversity of the taxon Pophyromonas gingivalis assessed by random amplified polymorphic DNA fingerprintig. Infect. Immun. 63: 2522-2531, 1995.

METZGER, Z.; BLASBALG, J.; DOTAN, M.; TSESIS, I.; WEISS, E. I. Characterization of coaggregation of Fusobacterium nucleatum PK1594 with six Porphyromonas gingivalis strains. J. Endod., v. 1, p. 50-54, 2009.

MISSAILIDIS, C. G.; UMEDA, J. E.; OTA-TSUZUKI, C.; ANZAI, D.; MAYER, M. P. A. Distribution of fimA genotypes of Porphyromonas gingivalis in subjects with different periodontal conditions. Oral. Microbiol. Immunol., v. 19, p. 224-229, 2004.

MOScOSO, M.; GARCÍA, E. Transcriptional regulation of the capsular polysaccharide biosynthesis locus of streptococcus pneumoniae: a bioinformatic analysis. DNA Res., v. 3, p. 177-186, 2009.

NAKAGAWA, I.; AMANO, A.; KUBONIWA, M.; NAKAMURA, T.; KAWABATA, S.; HAMADA, S. Functional differences among FimA variants of Pophyromonas gingivalis and their effects on adhesion and invasion of human epithelial cells. Infect Immun., v. 70, p. 277-285, 2002.

NAKAGAWA, I.; INABA, H.; YAMAMURA, T.; KATO, T.; KAWAI, S.; OOSHIMA, T.; AMANO, A. Invasion of epithelial cells and proteolysis of cellular focal adhesion components by distinct types of Porphyromonas gingivalis fimbriae. Infect. Immun., v. 7 , p. $3773-3782,2006$.

NAKHJIRI, S. F.; PARK, Y.; YILMAZ, O.; CHUNG, W.O,; WATANABE, K.; EL-SABAENY, A.; PARK, K.; LAMONT, R.J. Inhibition of epithelial cell apoptosis by Porphyromonas gingivalis. FEMS Microbiol. Lett., v. 2, p. 145-149, 2001. 
NATTO, S.; BALJOON, M.; DAHLÉN, G.; BERGSTRÖM, J. Tobacco smoking and periodontal microflora in a Saudi Arabian population. J. Clin. Periodontol., v. 32, p. 549-555, 2005.

NEIDERS, M. E.; CHEN, P. B.; SUIDO, H. Heterogeneity of virulence among strains of Bacteroides gingivalis. J. Periodontal. Res., v. 24, p. 192-198, 1989.

NELSON, K. E.; FLEISCHMANN, R. D.; DEBOY, R. T. Complete genome sequence of the oral pathogenic Bacterium Porphyromonas gingivalis strain W83. J. Bacteriol., v. 185, p. 5591-5601, 2003.

OLIVER, R. C.; BROWN, L. J.; LOE, H. Periodontal diseases in the United States population. J. Periodontol. Res., v. 69, p. 269-278, 1998.

O'RIORDAN, K.; LEE, J. C. Staphylococcus aureus capsular polysaccharides. Clin. Microbiol. Rev., v. 1, p. 218-234, 2004.

OVODOV, Y. S. Capsular antigens of bacteria. Capsular antigens as the basis of vaccines against pathogenic bacteria. Biochemistry (Mosc)., v.71, p. 955-961, 2006.

ÖZMERIÇ N, PREUS HR, OLSEN I. Genetic diversity of Porphyromonas gingivalis and its possible importance to pathogenicity. Acta Odontol Scand. 58:183-187, 2000.

PALMER, R. M.; WILSON, R. F.; HASAN, A. S.; SCOTT, D. A. Mechanisms of action of environmental factors - tabacco smoking. J. Clin. Periodontol., v. 32, n. 6, p. 180-195, 2005.

PARK, Y.; YILMAZ, O.; JUNG, I. Y; LAMONT, R. J. Identification of Porphyromonas gingivalis genes specifically expressed in human gingival epithelial cells by using differential display reverse transcription-PCR. Infect. Immun., v. 72, p. 3752-3758, 2004.

PASTER, B. J.; BOCHES, S. K.; GALVIN, J. L.; ERICSON, R .E.; LAU, C. N.; LEVANOS, V.A.; SAHASRABUDHE, A.; DEWHIRST, F.E. Bacterial diversity in human subgingival plaque. J. Bacteriol., v. 12, p. 3770-3783, 2001.

PATHIRANA, R.D.; O'BRIEN-SIMPSON, N.M.; REYNOLDS, E.C. Host immune responses to Porphyromonas gingivalis antigens. Periodontol. 2000, v. 1, p. 218237, 2010.

PELTOLA H. Meningococcal vaccines. Current status and future possibilities. Drugs, v. 55, p.347-366, 1998.

PEREZ-CHAPARRO, P.J.; ROUILLON, A.; MINET, J.; LAFAURIE, G.I.; BONNAURE-MALLET, $M$. fimA genotypes and PFGE profile patterns in Porphyromonas gingivalis isolates from subjects with periodontitis. Oral Microbiol Immunol., v.24, p.423-426, 2009. 
PORWOLLIK, S.; WONG, R. M.; MCCLELLAND, M. Evolutionary genomics of Salmonella: gene acquisitions revealed by microarray analysis. Proc. Natl. Acad. Sci. U S A., v. 99, p. 8956-8961, 2002.

ROSEN, G.; SELA, M. N. Coaggregation of Porphyromonas gingivalis and Fusobacterium nucleatum PK 1594 is mediated by capsular polysaccharide and lipopolysaccharide. FEMS Microbiol. Lett., v. 2, p. 304-310, 2006.

ROTH, G. A.; ANKERSMIT, H. J.; BROWN, V. B.; PAPAPANOU, P. N.; SCHMIDT, A. M.; LALLA, E. Porphyromonas gingivalis infection and cell death in human aortic endothelial cells. FEMS Microbiol. Lett., v. 272, p. 106-113, 2007.

SAYERS, N. M.; GOMES, B. P.; DRUCKER, D. B.; BLINKHORN, A. S. Possible lethal enhancement of toxins from putative periodontopathogens by nicotine: implications for periodontal disease. J. Clin. Pathol., v. 50, p. 245-249, 1997.

SCOTT, D. A.; SINGER, D. L. Suppression of overt gingival inflammation in tobacco smokers - clinical and mechanistic considerations. Int. J. Dent. Hyg., v. 3, p. 104110, 2004.

SCHMIDT, M. A. LEEways: tales of EPEC, ATEC and EHEC. Cell. Microbiol., v.12, p. 1544-1552, 2010.

SIMS, T. J.; SCHIFFERLE, R. E.; ALI, R. W.; SKAUG, N.; PAGE, R. C. Immunoglobulin $\mathrm{G}$ response of periodontitis patients to Porphyromonas gingivalis capsular carbohydrate and lipopolysaccharide antigens. Oral Microbiol. Immunol., v. 16, p. 193-201, 2001.

SLOTS, J.; BRAGD, L.; WIKSTRÖM, M.; DAHLÉN, G. The occurrence of Actinobacillus actinomycetemcomitans, Bacteroides gingivalis and Bacteroides intermedius in destructive periodontal disease in adults. J. Clin. Periodontol., v. 13, p. 570-577, 1986.

SLOTS, J. Uptade on Actinobacillus actinomycetemcomitans and Porphyromonas gingivalis in human periodontal disease. J. Int. Acad. Periodontol., v. 1, p. 121126, 1999.

SOCRANSKY, S. S.; HAFFAJEE, A. D. Periodontal microbial ecology. Periodontol. 2000, v. 38, p. 135-187, 2005.

SOCRANSKY, S. S.; HAFFAJEE, A. D.; DZINK, J. L. Microbial complexes in subgingival plaque. J. Clin. Periodontol., v. 25, p. 134-144, 1998.

SOCRANSKY, S. S.; HAFFAJEE, A. D.; SMITH, C.; DUFF, G. W. Microbiological parameters associated with IL-1 gene polymorphisms in periodontitis patients. $\mathbf{J}$. Clin. Periodontol., v. 27, p. 810-818, 2000.

SOJAR, H.T.; SHARMA, A.; GENCO, R.J. Porphyromonas gingivalis fimbriae bind to cytokeratin of epithelial cells. Infect. Immun., v. 70, p.96-101, 2002. 
STATHOPOULOU, P. G.; GALICIA, J. C.; BENAKANAKERE, M. R.; GARCIA, C .A..; POTEMPA, J.; KINANE, D. F. Porphyromonas gingivalis induce apoptosis in human gingival epithelial cells through a gingipain-dependent mechanism. BMC Microbiol., v. 9, p. 1-12, 2009.

SUGANO, N.; IKEDA, K.; OSHIKAWA, M.; SAWAMOTO, Y.; TANAKA, H.; ITO, K. Differential cytokine induction by two types of Porphyromonas gingivalis. Oral Microbiol. Immunol., v. 19, p. 121-123, 2004.

TACHIBANA-ONO, M.; YOSHIDA, A.; KATAOKA, S.; ANSAI, T.; SHINTANI, Y.; TAKAHASHI, Y.; TOYOSHIMA, K.; TAKEHARA, T. Identification of the genes associated with a virulent strain of Porphyromonas gingivalis using the subtractive hybridization technique. Oral Microbiol Immunol., v. 23, p. 84-87, 2008.

TEANPAISAN, R.; DOUGLAS, C. W. I. Molecular fingerprinting of Porphyromonas gingivalis by $\mathrm{PCR}$ of repetitive extragenic palindromic (REP) sequences and comparison with other fingerprinting methods. J. Med. Microbiol., v. 48, p. 741749, 1999.

TEIXEIRA, S. R. L.; MATARAZZO, F.; FERES, M.; FIGUEIREDO, L. C.; FAVERI, M.; SIMIONATO, M. R. L.; MAYER M. P. A. Quantification of Porphyromonas gingivalis and fimA genotypes in smoker chronic periodontitis. J. Clin. Periodontol., v. 36, p. 482-487, 2009.

THE DEPARTMENT OF ZOOLOGY, University of Oxford, UK. Pubmlst. 1995. Disponivel em: http://www.pubmlst.org/pgingivalis. Acesso em : 10/06/2011.

UMEDA, J. E.; MISSAILIDIS, C.; LONGO, P. L.; ANZAI, D.; WIKSTROM, M.; MAYER, M. P. A. Adhesion and invasion to epithelial cells by fimA genotypes of Porphyromonas gingivalis. Oral Microbiol. Immunol., v. 21, p. 415-419, 2006.

URNOWEY, S.; ANSAI, T.; BITKO, V.; NAKAYAMA, K..; TAKEHARA, T.; BARIK, S. Temporal activation of anti- and pro-apoptotic factors in human gingival fibroblasts infected with the periodontal pathogen, Porphyromonas gingivalis: potential role of bacterial proteases in host signalling. BMC Microbiol., v. 8, p. 6-26, 2006.

VAN DEN ENT, F.; VINKENVLEUGEL, T.M; IND, A.; WEST, P.; VEPRINTSEV, D.; NANNINGA, N.; DEN BLAAUWEN, T.; LÖWE, J. Structural and mutational analysis of the cell division protein FtsQ. Mol Microbiol, v. 68, p.110-123, 2008.

VAN WINKELHOFF, A. J.; APPELMELK, B. J.; KIPPUW, N.; DE GRAAFF, J. Kantigens in Porhyromonas gingivalis are associated with virulence. Oral Microbiol. Immunol., v. 8, p. 259-265, 1993.

VAN WINKELHOFF, A. J.; VAN STEENBERGEN, T. J.; DE GRAAFF, J. The role of black-pigmented Bacteroides in human oral infections. J. Clin. Periodontol., v. 15, p. 145-155, 1988. 
VERNAL, R.; LEÓN, R.; SILVA, A.; VAN WINKELHOFF, A. J.; GARCIA-SANZ, J. A.; SANZ, M. Differential cytokine expression by human dendritic cells in response to different Porphyromonas gingivalis capsular serotypes. J. Clin. Periodontol., v. 10, p. 823-829, 2009.

WATANABE, K.; YAMAJI, Y.; UMEMOTO, T. Correlation between cell-adherent activity and surface structure in Porphyromonas gingivalis. Oral Microbiol. Immunol., v. 7, p. 357-363, 1992.

WRIGHT, A. C.; POWELL, J. L.; TANNER, M. K.; ENSOR, L. A.; KARPAS, A. B.; MORRIS JR, J. G.; SZTEIN, M. B. Differential expression of Vibrio vulnificus capsular polysaccharide. Infect. Immun., v. 5, p. 2250-22

YILMAZ, O; WATANABE, K.; LAMONT, R. J. Invovement of integrins in fimbriaemediated binding and invasion by Porphyromonas gingivalis. Cel Microbiol., v. 5, p. 305-314, 2002.

YILMAZ, O.; JUNGAS, T.; VERBEKE, P.; OJCIUS, D. M. Activation of the phosphatidylinositol 3-kinase/Akt pathway contributes to survival of primary epithelial cells infected with the periodontal pathogen Porphyromonas gingivalis. Infect. Immun., v. 7, p. 3743-3751, 2004.

YOSHIMURA, F.; URAKAMI, Y.; NISHIKAWA, K.; HASEGAWA, Y.; KAWAMINAMI, S. Surface components of Porphyromonas gingivalis. J. Periodont. Res., v. 44, p. 1-12, 2008.

YOSHIMURA, M.; OHARA, N.; KONDO, Y. Proteome analysis of Porphyromonas gingivalis cells placed in a subcutaneous chamber of mice. Oral Microbiol. Immunol., v. 23, p. 413-418, 2008. 